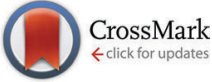

Cite this: New J. Chem., 2017 41,1940

Received 9th November 2016 Accepted 15th January 2017

DOI: $10.1039 / c 6 n j 03508 f$

rsc.li/njc

\section{Trinuclear (aminonitrone) Zn" complexes as key intermediates in zinc(II)-mediated generation of 1,2,4-oxadiazoles from amidoximes and nitriles $\dagger$}

\author{
Dmitrii S. Bolotin, ${ }^{a}$ Mikhail V. Il'in, ${ }^{a}$ Alexander S. Novikov, ${ }^{a}$ Nadezhda A. Bokach, ${ }^{a}$ \\ Vitalii V. Suslonov ${ }^{b}$ and Vadim Yu. Kukushkin ${ }^{\star a}$
}

\begin{abstract}
Aliphatic and aromatic amidoximes $\mathrm{RC}\left(\mathrm{NH}_{2}\right)=\mathrm{NOH}\left(\mathrm{R}=\mathrm{Et},{ }^{t} \mathrm{Bu}, \mathrm{Ph}, \mathrm{O}-\mathrm{ClC}_{6} \mathrm{H}_{4}\right)$ react with $\mathrm{Zn}(\mathrm{OAc})_{2}$. $2 \mathrm{H}_{2} \mathrm{O}$ in $\mathrm{Me}_{2} \mathrm{CO}$ giving $\left[\mathrm{Zn}(\mathrm{OAC})_{2}\left\{\mathrm{RC}\left(\mathrm{NH}_{2}\right)=\mathrm{NOH}\right\}_{2}\right]$ complexes bearing $\mathrm{N}$-bound amidoximes, which are involved in a moderate strength $\left(7.3-11.9 \mathrm{kcal} \mathrm{mol}^{-1}\right.$ by the DFT calculations) intramolecular resonanceassisted hydrogen bonding between the oxime $\mathrm{HO}$ group and the oxo group of the acetate ligand. The complexes $\left[\mathrm{Zn}(\mathrm{OAc})_{2}\left\{\mathrm{RC}\left(\mathrm{NH}_{2}\right)=\mathrm{NOH}\right\}_{2}\right]$ react with excess $\mathrm{Zn}(\mathrm{OTf})_{2}$ in acetone accomplishing trinuclear species $\left[\mathrm{Zn}_{3}\left(\mu_{2}-\mathrm{OAc}\right)_{2}\left\{\mu_{2}-\mathrm{RC}\left(\mathrm{NH}_{2}\right)=\mathrm{N}(\mathrm{H}) \mathrm{O}\right\}_{4}\left(\mathrm{H}_{2} \mathrm{O}\right)_{6}\right](\mathrm{OTf})_{4}$ featuring both $\mathrm{O}$-ligated amidoximes-stabilized in the aminonitrone tautomeric form-and bridging acetate ligands. The aminonitrone trinuclear species were also prepared directly via the reaction of the amidoximes with $\mathrm{Zn}(\mathrm{OTf})_{2}$ in EtOAc; ethyl acetate in this reaction plays the role of the acetate donor and $\mathrm{OAc}^{-}$is generated in situ via $\mathrm{Zn}^{\prime \prime}$-mediated hydrolysis of EtOAc. Although $\left[\mathrm{Zn}(\mathrm{OAC})_{2}\left\{\mathrm{RC}\left(\mathrm{NH}_{2}\right)=\mathrm{NOH}\right\}_{2}\right]$ are inactive toward dimethylcyanamide, the $\left[\mathrm{Zn}_{3}\left(\mu_{2}-\mathrm{OAC}\right)_{2}\left\{\mu_{2}-\mathrm{RC}\left(\mathrm{NH}_{2}\right)=\mathrm{N}(\mathrm{H}) \mathrm{O}_{4}\left(\mathrm{H}_{2} \mathrm{O}\right)_{6}\right](\mathrm{OTf})_{4}\right.$ complexes readily react with $\mathrm{Me}_{2} \mathrm{NCN}$ giving, as a

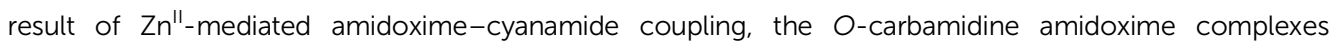
$\left[\mathrm{Zn}(\mathrm{OTf})_{2}\left\{\mathrm{RC}\left(\mathrm{NH}_{2}\right)=\mathrm{NOC}\left(\mathrm{NMe}_{2}\right)=\mathrm{NH}\right\}_{2}\right]$. All synthesized compounds were characterized by HRESI-MS, FTIR, ${ }^{1} \mathrm{H}-$, CP-MAS TOSS ${ }^{13} \mathrm{C}\left\{{ }^{1} \mathrm{H}\right\}-$, and ${ }^{13} \mathrm{C}\left\{{ }^{1} \mathrm{H}\right\}$ NMR, and additionally by single-crystal $\mathrm{X}$-ray diffraction for eight species. Different types of non-covalent interactions in the obtained solid-state structures were studied by DFT calculations (M06-2X/6-311+G(d,p) level of theory) and topological analysis of the electron density distribution within the formalism of Bader's theory (QTAIM method).
\end{abstract}

\section{Introduction}

The zinc(II)-mediated reaction between amidoximes and nitriles ${ }^{1}$ is among the most facile and expedient routes for the synthesis of 1,2,4-oxadiazoles - a class of heterocycles that exhibit a wide range of biomedical ${ }^{2}$ (e.g., antibacterial, ${ }^{3}$ antibiotic, ${ }^{4}$ antimalarial, ${ }^{5}$ anticancer, ${ }^{6}$ anticonvulsant, ${ }^{7}$ immunomodulating $^{8}$ and antihistaminic ${ }^{9}$ ) properties. These ring systems also act as active antihypertensive agents, ${ }^{10}$ selective inhibitors

\footnotetext{
${ }^{a}$ Institute of Chemistry, Saint Petersburg State University, Universitetskaya Nab., 7/9, Saint Petersburg, Russian Federation. E-mail: v.kukushkin@spbu.ru

${ }^{b}$ Center for X-ray Diffraction Studies, Saint Petersburg State University,

Universitetskii Pr., 26, Saint Petersburg, Russian Federation

$\dagger$ Electronic supplementary information (ESI) available: Analytical and spectroscopy data; the structures of the $O$-iminoacylated oximes; spectra of 2a-d, [3a-d] $(\mathrm{OTf})_{4}$, $\left[\mathbf{4 a - c}(\mathrm{OTf})_{2}\right]$, and [5a-d](OTf); crystal data for $\mathbf{2 a - c},[3 \mathbf{a}](\mathrm{OTf})_{4},[\mathbf{4 b}(\mathrm{OTf})(\mathrm{EtOH})](\mathrm{OTf})$, $\left[\mathbf{4 c}(\mathrm{OTf})_{2}\right],[\mathbf{5 a}](\mathrm{OTf})$, and [5d](OTf); theoretical study of bonding situation in solid state structures of 2 and [4](OTf $)_{2}$, calculated Wiberg bond indices for selected bonds in 2a-c; Cartesian atomic coordinates of model structures; crystallographic information files for $2 \mathbf{a}-\mathbf{c}$, $[3 \mathbf{a}](\mathrm{OTf})_{4},[\mathbf{4 b}(\mathrm{OTf})(\mathrm{EtOH})](\mathrm{OTf}),\left[\mathbf{4 c}(\mathrm{OTf})_{2}\right]$, [5a](OTf), and [5d](OTf). CCDC 1503999-1504006. For ESI and crystallographic data in CIF or other electronic format see DOI: 10.1039/c6nj03508f
}

of $11 \beta$-hydroxysteroid dehydrogenase, ${ }^{11}$ dopamine D3 receptor ligands, ${ }^{12}$ glycogen phosphorylase inhibitors, ${ }^{13}$ and elective agonists of free fatty acid receptor, ${ }^{14}$ and serve as useful precursors for materials science for mastering liquid crystals, ${ }^{15}$ nanoporous networks, ${ }^{16}$ and insensitive energetic materials. ${ }^{17}$

Recent synthetic works ${ }^{1 a, 18}$ helped to obtain some data partially explaining the mechanism of heterocyclization. In particular, intermediates $\mathbf{A}$ and $\mathbf{B}$ (Scheme 1) in the reaction between $\mathrm{R}_{2} \mathrm{NCN}$ and $\mathrm{R}^{\prime}\left(\mathrm{NH}_{2}\right) \mathrm{C}=\mathrm{NOH}$ in the presence of zinc(II) in undried EtOAc were trapped and identified. These data allowed the assumption that the overall reaction starts from the $\mathrm{Zn}^{\mathrm{II}}$-mediated amidoxime-nitrile coupling. However, blackboxed intermediate zinc(II) complexes featuring coordinated amidoximes and/or nitriles were neither isolated/characterized nor identified in situ by physicochemical methods.

Being interested in understanding the detailed mechanism of $\mathrm{Zn}^{\mathrm{II}}$-mediated generation of 1,2,4-oxadiazoles from amidoximes and nitriles ${ }^{1 a, 18}$ and in further development of coordination chemistry of amidoximes ( $\rightleftharpoons$ aminonitrones) (for our review on this subject see ref. 19), we synthesized novel zinc(II) species featuring amidoximes and studied their reactivity toward 


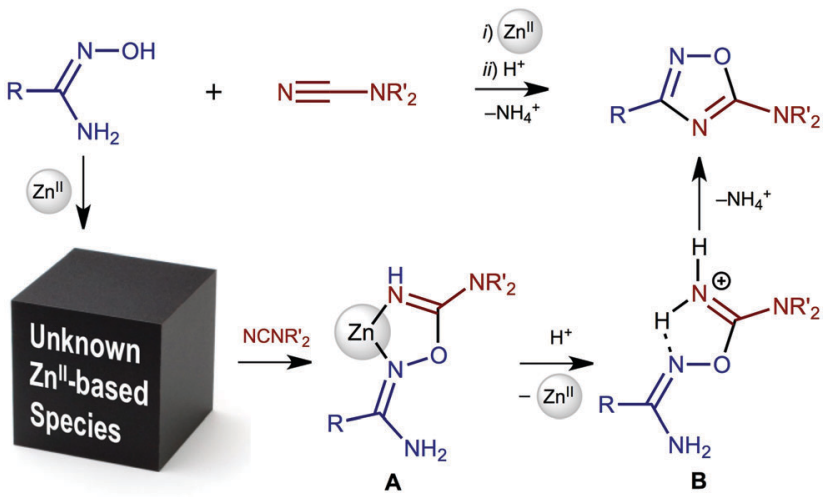

Scheme 1 Simplified mechanism of zinc(II)-mediated generation of 1,2,4oxadiazoles.

$\mathrm{Me}_{2} \mathrm{NCN}$ as a representative of cyanamides. The main idea of this work was to obtain experimental data fully explaining the mechanism of zinc(II)-mediated generation of 1,2,4-oxadiazoles from amidoximes and nitriles to provide a solid background for rational choice of reactants and reaction conditions.

The scenario of this study was as follows. Firstly, we synthesized zinc(II) amidoxime species and determined ligand coordination patterns (amidoxime and aminonitrone forms) and verified the structures of these complexes both experimentally and theoretically. Secondly, we studied the reactivity of the (amidoxime) $\mathrm{Zn}^{\mathrm{II}}$ and (aminonitrone) $\mathrm{Zn}^{\mathrm{II}}$ complexes toward $\mathrm{Me}_{2} \mathrm{NCN}$ as a model cyanamide substrate. Based on all these data we, thirdly, described the mechanism of zinc(II)-mediated generation of 1,2,4-oxadiazoles from amidoximes and nitriles. All the obtained data along with the corresponding discussions are consistently disclosed in sections that follow.

\section{Results and discussion}

Generation of zinc(II) amidoxime and aminonitrone complexes

As starting materials for the generation of zinc(II) amidoxime and aminonitrone complexes we used the aromatic and aliphatic amidoximes $\mathrm{RC}\left(\mathrm{NH}_{2}\right)=\mathrm{NOH}\left(\mathrm{R}=\mathrm{Ph} \mathrm{1a}, o-\mathrm{ClC}_{6} \mathrm{H}_{4}\right.$ 1b, Et 1c, ${ }^{t} \mathrm{Bu}$ 1d $)$ and, as sources of zinc(II), the salts $\mathrm{Zn}(\mathrm{OTf})_{2}$ and $\mathrm{Zn}(\mathrm{OAc})_{2} \cdot 2 \mathrm{H}_{2} \mathrm{O}$. We also applied $\mathrm{Me}_{2} \mathrm{CO}$ and EtOAc as solvents in our synthetic experiments to understand the mysterious effect of ethyl acetate on the facilitation of the $\mathrm{Zn}^{\mathrm{II}}$-mediated reaction. ${ }^{1 a}$

We started our experiments under conditions, which were applied for synthetically optimized $\mathrm{Zn}{ }^{\mathrm{II}}$-mediated amidoximecyanamide coupling. ${ }^{1 a}$ When undried EtOAc was employed as a solvent in the reaction between 1a-d and $\mathrm{Zn}(\mathrm{OTf})_{2}$ (Scheme 2, c2), we observed the generation of trinuclear complexes $[\mathbf{3 a}-\mathbf{d}](\mathrm{OTf})_{4}$. We varied molar ratios between 1a-d and $\mathrm{Zn}(\mathrm{OTf})_{2}$ from $1: 1$ to $6: 1$, including $2: 1$, and found that the trinuclear complexes are formed in all these combinations. The highest yields of $[3 \mathbf{3}-\mathbf{d}](\mathrm{OTf})_{4}(70-87 \%)$ were achieved when the molar ratio between 1a-d and $\mathrm{Zn}(\mathrm{OTf})_{2}$ was $4: 3$ and the reaction mixture was refluxed for $30 \mathrm{~min}$ in EtOAc (C2). We believe that in [3a-d] $(\mathrm{OTf})_{4}$, two bridging $\mathrm{OAc}^{-}$ligands are derived from $\mathrm{Zn}^{\mathrm{II}}-$ mediated hydrolysis of EtOAc; a relevant metal-mediated hydrolysis of ethyl acetate has previously been repeatedly reported (see, for example, ref. 20).

Concurrently, treatment of 1a-d with $\mathrm{Zn}(\mathrm{OTf})_{2}$ in a molar ratio $2: 1$ in acetone either at $\mathrm{RT}$ or $50{ }^{\circ} \mathrm{C}$ for 1 day gives a broad spectrum of products that we failed to separate. After keeping the reaction mixture for 1 week at $20-25{ }^{\circ} \mathrm{C}$ we observed the formation of $[\mathbf{1 a}-\mathbf{d H}](\mathrm{OTf})$ in the solution along with some amount of zinc-containing precipitate.

We assumed that the presence of acetate favors the generation of the trinuclear complexes. Accordingly, 1a-d were treated with $\mathrm{Zn}(\mathrm{OAc})_{2} \cdot 2 \mathrm{H}_{2} \mathrm{O}$ in a molar ratio $2: 1$ in acetone at $50{ }^{\circ} \mathrm{C}$ and we observed the fast ( $5 \mathrm{~min}$ ) formation of $\mathbf{2 a - d}$ that were isolated in $75-82 \%$ yields (Scheme 2, a2). Complexes 2a-d were easily transformed into the corresponding $[\mathbf{3 a}-\mathbf{d}](\mathrm{OTf})_{4}$ when 2a-d reacted with 2 equiv. of $\mathrm{Zn}(\mathrm{OTf})_{2}$ and 2 equiv. of $1 \mathrm{a}-\mathbf{d}$ in undried acetone for $5 \mathrm{~min}$ at $50{ }^{\circ} \mathrm{C}(\mathrm{b} 2)$. The reverse processwhich includes the transformation of $[3 \mathbf{a}-\mathbf{d}](\mathrm{OTf})_{4}$ to $2 \mathbf{a}-\mathbf{d}-$ was not realized and the addition of the corresponding amidoxime ( 2 equiv.) and NaOAc (4 equiv.) to [3a-d] $(\mathrm{OTf})_{4}$ in acetone ( $5 \mathrm{~min}, 50{ }^{\circ} \mathrm{C}$ or $1 \mathrm{~d}, \mathrm{RT}$ ) led to amorphous zinc hydroxides and $[\mathbf{1 a}-\mathbf{d H}](\mathrm{OAc})$.

\section{Zinc(II)-mediated amidoxime-cyanamide coupling}

In order to study the reactivity of the zinc(II)-bound oximes, we reacted complexes 2a-d and [3a-d] $(\mathrm{OTf})_{4}$ with dimethylcyanamide as a model nitrile substrate. When complexes [3a-d] $(\mathrm{OTf})_{4}$ were treated with 4 equiv. of $\mathrm{Me}_{2} \mathrm{NCN}$ (EtOAc, RT, $3 \mathrm{~h}$ ), the reaction yielded either imino complexes [ $\left.\mathbf{4 a - c}(\mathrm{OTf})_{2}\right]\left(\mathrm{R}=\mathrm{Ph}, o-\mathrm{ClC}_{6} \mathrm{H}_{4}\right.$, Et; Scheme 2, d2), or iminium salt [5d](OTf) $\left(\mathrm{R}={ }^{t} \mathrm{Bu}\right.$; $\mathrm{d} 2$ and f2) in excellent (93-98\%) yields. Complex [4d(OTf $\left.)_{2}\right]$ was not obtained due to the steric hindrance of the bulky ${ }^{t} \mathrm{Bu}$ group, which precluded the formation of the chelated complex and gave only uncomplexed [5d](OTf). Imino complexes $\left.[\mathbf{4 a - c ( O T f})_{2}\right]$ and salt [5d](OTf) were also generated by the direct reaction of $\mathbf{1 a - d}$ with $\mathrm{Me}_{2} \mathrm{NCN}$ and $\mathrm{Zn}(\mathrm{OTf})_{2}$ (EtOAc, RT, $3 \mathrm{~h}$; e2). The yields of $\left[\mathbf{4 a}-\mathbf{c}(\mathrm{OTf})_{2}\right]$ and $[\mathbf{5 d}](\mathrm{OTf})$ obtained via route e 2 are comparable with the corresponding overall yields determined for routes $\mathrm{c} 2$ and $\mathrm{d} 2$ (approx. 70-80\%). Complexes 2a-d do not react with $\mathrm{Me}_{2} \mathrm{NCN}$ at RT even for $24 \mathrm{~h}$ and a mixture of yet unidentified products was formed when the reaction was attempted at $50{ }^{\circ} \mathrm{C}$ for $3 \mathrm{~h}$.

In our previous study, we demonstrated that substituted cyanamides and nitriles RCN $\left(\mathrm{R}=\mathrm{Alk}, \mathrm{Ar}, \mathrm{NR}_{2}\right)$ are involved in the coupling with amidoximes in the presence of $\mathrm{ZnCl}_{2}$ achieving the complexes $\left[\mathrm{ZnCl}_{2}\left\{\mathrm{~N}(\mathrm{H})=\mathrm{C}(\mathrm{R}) \mathrm{ONC}\left(\mathrm{NH}_{2}\right) \mathrm{R}^{\prime}\right\}\right]$ and this reaction is metal-mediated. ${ }^{1 a}$ Herein, we demonstrate that aminonitrone trinuclear species [3a-d] $(\mathrm{OTf})_{4}$ can also be involved in the zinc(II)-mediated coupling with $\mathrm{Me}_{2} \mathrm{NCN}$ and (aminonitrone) $\mathrm{Zn}^{\mathrm{II}}$ complexes, viz. [3a-d] (OTf $)_{4}$, serve as key intermediates of the coupling. ${ }^{1 a}$

Our observations provide a background for a deeper understanding of the mechanism of $\mathrm{Zn}^{\mathrm{II}}$-mediated amidoximecyanamide coupling. Insofar as 2a-d and [3a-d] $(\mathrm{OTf})_{4}$ demonstrated different reactivities toward $\mathrm{Me}_{2} \mathrm{NCN}$, one can assume a strong effect of the coordination pattern of the amidoxime on the reaction. Thus, in $\mathbf{2 a - d}$, the $N$-coordinated amidoxime-which 


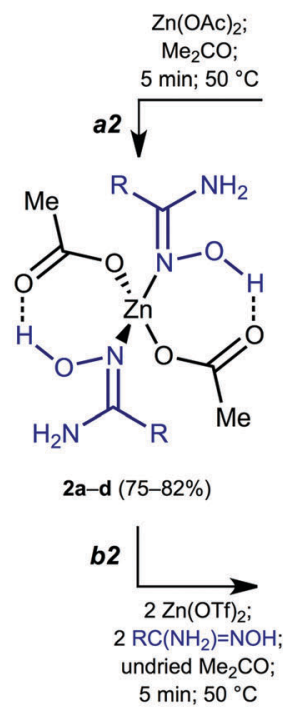

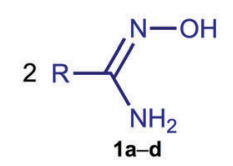
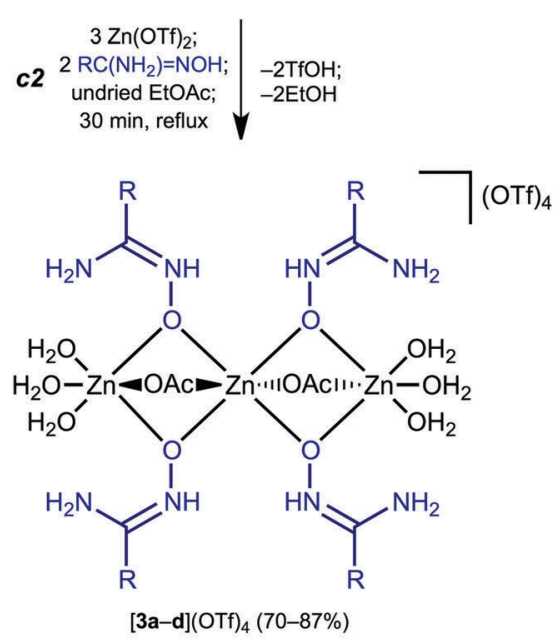

$2 \mathrm{Zn}(\mathrm{OTf})_{2}$

$2 \mathrm{RC}\left(\mathrm{NH}_{2}\right)=\mathrm{NOH}$

$4 \mathrm{NCNMe}_{2}$

EtOAc, $3 \mathrm{~h}, \mathrm{RT}$

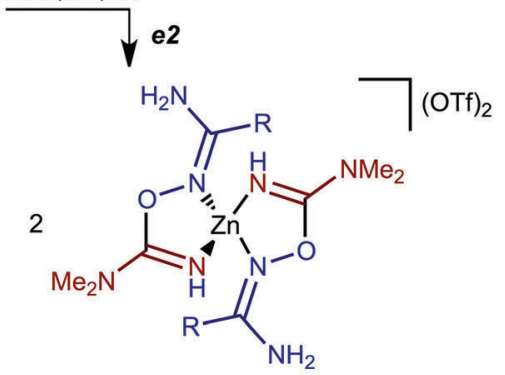

[4a-c](OTf) 2 (d2: 93-98\%; e2: 76-82\%)

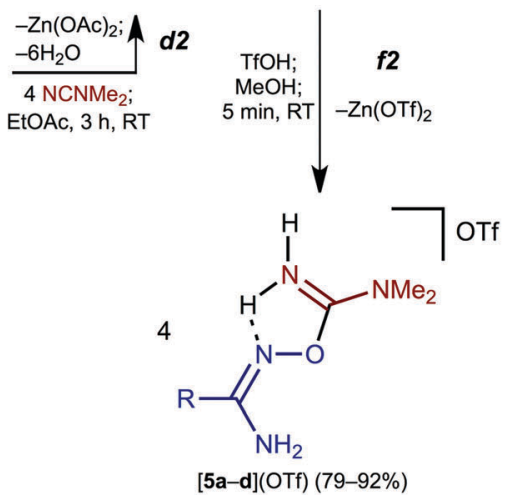

Scheme 2 The studied reactions.

is involved in the formation of intramolecular resonance-assisted hydrogen bonding (RAHB; for recent works on this type of hydrogen bonding see ref. 21) between the oxime HO group and the oxo group of the acetate ligand-does not react with $\mathrm{Me}_{2} \mathrm{NCN}$. In $[3 \mathbf{3}-\mathbf{d}](\mathrm{OTf})_{4}, O$-coordinated amidoxime in its aminonitrone form reacted with $\mathrm{Me}_{2} \mathrm{NCN}$ under mild conditions (RT, $3 \mathrm{~h}$ ). The latter observation is in agreement with the theoretical calculation data, which demonstrated that oxime-nitrile coupling proceeds via the aminonitrone form of the nucleophile. ${ }^{22}$

\section{Analytical and spectroscopy data}

Complexes 2a-d, [3a-d] $(\mathrm{OTf})_{4},\left[\mathbf{4 a - c}(\mathrm{OTf})_{2}\right]$, and salts $[\mathbf{5 a - d}](\mathrm{OTf})$ gave satisfactory $\mathrm{C}, \mathrm{H}$, and $\mathrm{N}$ elemental analysis results for the proposed formulas, and these species were also characterized by high-resolution ESI-MS, FTIR, ${ }^{1} \mathrm{H}$-, and CP-MAS TOSS ${ }^{13} \mathrm{C}\left\{{ }^{1} \mathrm{H}\right\}$ (for poorly soluble 2a-d, [3a-d] (OTf) , and [5d](OTf)) or ${ }^{13} \mathrm{C}\left\{{ }^{1} \mathrm{H}\right\}$ NMR spectroscopy (for $\left[\mathbf{4 a}-\mathbf{c}(\mathrm{OTf})_{2}\right]$ and $[\mathbf{5 a}-\mathbf{c}](\mathrm{OTf})$ exhibiting sufficient solubility) and additionally by single-crystal X-ray diffraction for eight species (2a-c, [3a](OTf $)_{4},[\mathbf{4 b}(\mathrm{OTf})(\mathrm{EtOH})](\mathrm{OTf})$, $\left[\mathbf{4 c}(\mathrm{OTf})_{2}\right],[5 \mathrm{a}](\mathrm{OTf})$, and [5d](OTf)).

For a detailed description of the characterization see the ESI. $\dagger$ Briefly, the IR spectra of 2a-d, [3a-d] $(\mathrm{OTf})_{4}$, and [4a-c(OTf $\left.)_{2}\right]$, exhibit one $\nu(\mathrm{C}=\mathrm{N})$ band in the range $1678-1638 \mathrm{~cm}^{-1}$, which is specific to amidoximes. ${ }^{19}$ The spectra of $2 \mathbf{a}-\mathbf{d}$ and $[3 \mathbf{3 a}-\mathbf{d}](\mathrm{OTf})_{4}$ also display three strong to very strong bands in the region 1608$1340 \mathrm{~cm}^{-1}$ from the $\nu(\mathrm{C}=\mathrm{O})$ of the ligated acetate group. A characteristic feature of the ${ }^{1} \mathrm{H}$ NMR spectra of $2 \mathbf{2 a}-\mathbf{d}$ and $[3 \mathbf{a}-\mathbf{d}](\mathrm{OTf})_{4}$ recorded in $\left(\mathrm{CD}_{3}\right)_{2} \mathrm{CO}$ is the absence of the $\mathrm{OH}$ and
$\mathrm{ONH}$ signals due to a fast exchange with water protons. Another feature is the availability of broad singlets attributed to the $\mathrm{NH}_{2}$ resonances at 6.40-5.29 (for 2a-d) and 8.48-7.93 ppm (for $\left.[3 \mathbf{a}-\mathbf{d}](\mathrm{OTf})_{4}\right)$. The low-field shift of the signal in the spectra of $[3 a-d](O T f)_{4}$ is probably due to the positive charge on the $\mathrm{HNCNH}_{2}$ moiety provided by the stabilization of $\mathbf{1 a - d}$ ligands in the aminonitrone form.

\section{X-ray structure determination, QTAIM and NBO analysis of the bonding}

(i) The structures of the trinuclear complexes and aminonitrone coordination pattern. In the molecular structure of trinuclear $[\mathbf{3 a}](\mathrm{OTf})_{4}$, the coordination polyhedra of the zinc(II) centers display typical octahedral geometries (Fig. 1). All bond angles around the zinc(II) centers range from $73.29(16)$ to $105.95(17)^{\circ}$, the $\mathrm{Zn}-\mathrm{O}[1.944(4)-2.1460(4) \AA]$ and $\mathrm{N}(2)-\mathrm{C}(1)$ $[1.319(10)-1.330(8) \AA]$ bonds are normal single bonds, ${ }^{23}$ whereas the $\mathrm{O}(1)-\mathrm{N}(2)$ distances $[1.344(7)-1.357(7) \AA]$ are shorter than the usual $\mathrm{O}-\mathrm{N}^{\mathrm{Sp}^{2}}$ bonds and typical for $\mathrm{O}$-ligated amidoximes in the aminonitrone form. ${ }^{19}$ The $\mathrm{N}(1)-\mathrm{C}(1)$ distance values [1.298(8)$1.309(8) \AA]$ indicate an intermediate order between typical single and double bonds, ${ }^{23}$ which reflects the amide character of these bonds. The carbamidoxime groups are in the $Z$-configuration. The intermolecular $\mathrm{H}$-bonds are between the aminonitrone $\mathrm{NH}$ atom and the $\mathrm{O}$ atom of one of the triflate [N . O O 2.749-2.789 $\AA$; $\left.\mathrm{N}-\mathrm{H} \cdots \mathrm{O} 155.11-167.27^{\circ}\right]$. Hydrogen bonds between the amide $\mathrm{H}$ atoms and the triflate $\mathrm{O}$ atoms and between the ligated $\mathrm{H}_{2} \mathrm{O}$ and the triflate counter-ions were observed. It is noteworthy 


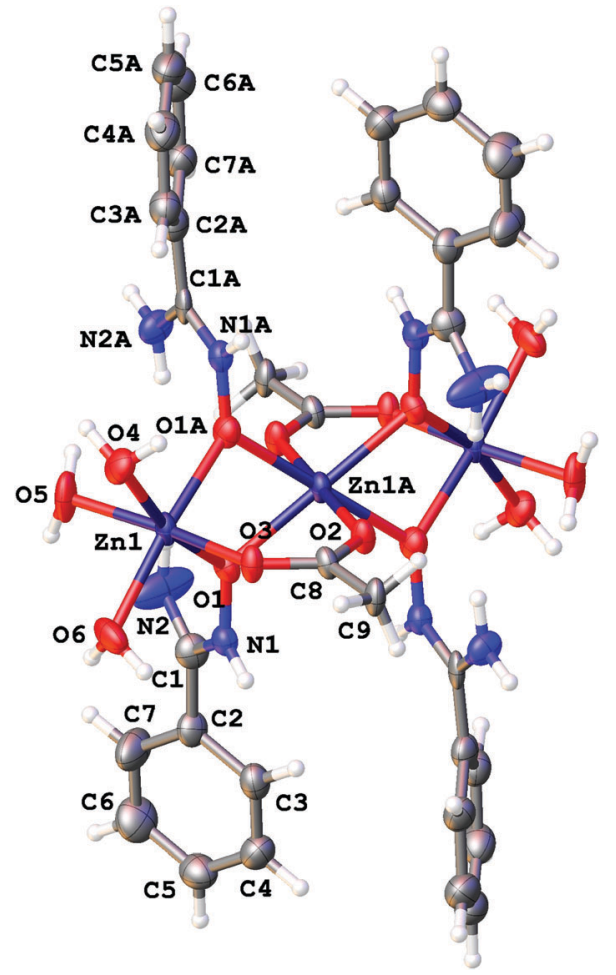

Fig. 1 The structure of $[3 a]^{4+}$ showing the atomic numbering scheme. Thermal ellipsoids are given at the $50 \%$ probability level.

that trinuclear complexes bearing bridging carboxylate ligands linking the three zinc centers in the $\left\{\mathrm{Zn}\left(\mu_{2}-\mathrm{O}_{2} \mathrm{CR}\right) \mathrm{Zn}\left(\mu_{2}-\mathrm{O}_{2} \mathrm{CR}\right) \mathrm{Zn}\right\}$ $(\mathrm{R}=\mathrm{Me}, \mathrm{Ph})$ moieties are known (for recent examples see ref. 24).

Amidoximes and their deprotonated forms possess three nucleophilic centers, viz. two $\mathrm{N}$ - and one $\mathrm{O}$ atoms, therefore several types of coordination modes for these ligands can be realized. In our recent review, ${ }^{19}$ we analyzed the existing data on amidoxime coordination, verified nine patterns, and led to the conclusion that $N$-binding (as in 2a-d) is the conventional coordination pattern. The binding in the aminonitrone form, viz. $[\mathrm{M}]\left\{\mathrm{ON}(\mathrm{H})=\mathrm{C}\left(\mathrm{NR}_{2}\right) \mathrm{R}^{\prime}\right\}$ or $[\mathrm{M}]_{2}\left\{\mu_{2}-\mathrm{ON}(\mathrm{H})=\mathrm{C}\left(\mathrm{NR}_{2}\right) \mathrm{R}^{\prime}\right\}$ (Fig. 2) less common.

If the former type (A) of coordination was documented for $\mathrm{U}^{\mathrm{VI}},{ }^{25} \mathrm{Pu}^{\mathrm{IV}},{ }^{26} \mathrm{Ge}^{\mathrm{IV}},{ }^{19} \mathrm{Sn}^{\mathrm{IV}}, 19$ and $\mathrm{Fe}^{\mathrm{III} 19,27}$ species, the latter type (B)-which we observed in [3a-d] $(\mathrm{OTf})_{4}$-is substantially less abundant and it was previously observed only for a molybdenum(vi) center. ${ }^{19,28}$ The difference in bonding pattern can be rationalized by the application of Pearson's HSAB principle ${ }^{29}$ and charge considerations. Accordingly, the aminonitrone form coordinates to the harder and highly charged $\left\{\mathrm{Zn}_{3}(\mathrm{OAc})_{2}\right\}^{4+}$ moiety via a "hard" and negatively charged oxygen center, whereas neutral amidoximes tend to ligate to the neutral $\mathrm{Zn}(\mathrm{OAc})_{2}$ species, as in 2a-d, via a relatively "soft" nitrogen center. An additional stabilization of $\mathbf{2 a - d}$ by resonance-assisted hydrogen bonding (see below) should be taken into account.

(ii) The structures of monomeric 2a-c involving resonanceassisted hydrogen bonding. In the molecular structures of $2 a-c$, the coordination polyhedra exhibit a distorted tetrahedral geometry (Fig. 3). All bond angles around the zinc(II) centers range from 93.58(5) to $122.11(7)^{\circ}$. The $\mathrm{Zn}-\mathrm{O}$ distances [1.9538(19)-1.9975(19) $\left.\mathrm{A}\right]$
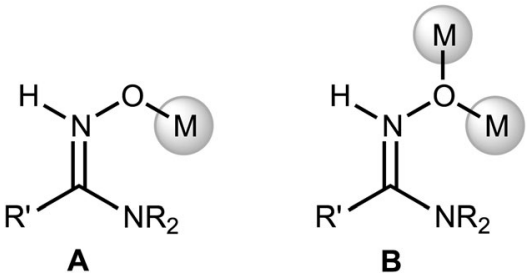

Fig. 2 O-Coordinated amidoxime moiety.

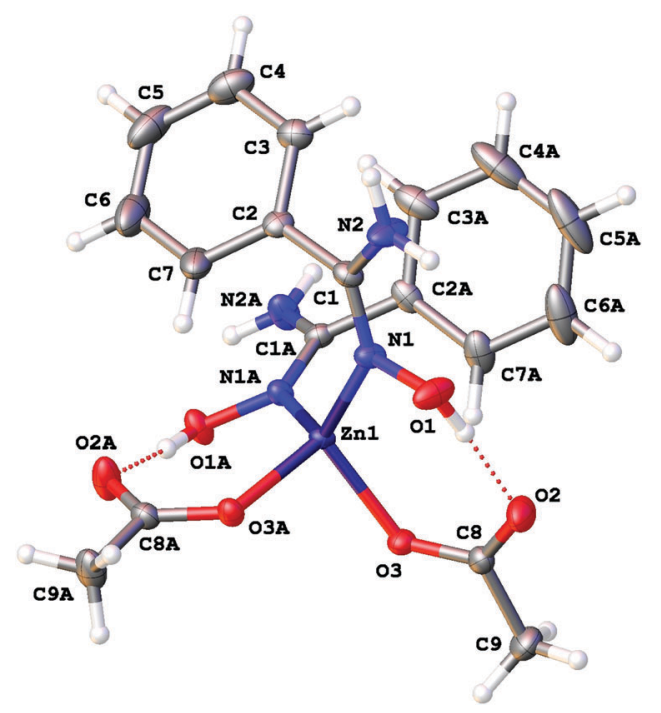

Fig. 3 The molecular structure of $\mathbf{2 a}$ showing the atomic numbering scheme. Thermal ellipsoids are given at the $50 \%$ probability level.

are specific for the (acetate) $\mathrm{Zn}^{\mathrm{II}}$ bonds. ${ }^{30}$ The $\mathrm{Zn}-\mathrm{N}$ bond lengths [1.9890(17)-2.0043(18) $\AA]$ exhibit values characteristic for (oxime) $\mathrm{Zn}^{\mathrm{II}}$ bonds. ${ }^{30 a}$ The $\mathrm{O}(1)-\mathrm{N}(2)$ distances [1.414(12)-1.425(2) $\left.\AA\right]$ are typical for $N$-ligated amidoximes. ${ }^{19}$ The $\mathrm{N}(2)-\mathrm{C}(1)[1.334(2)-1.342(4) \AA]$ and $\mathrm{O}(1)-\mathrm{C}(2)[1.328(2)-1.366(4) \AA]$ bonds are normal single bonds. ${ }^{23}$ The N(1)-C(1) distances [1.296(4)-1.3042(18) ̊] indicate an intermediate order between typical single and double bonds ${ }^{23}$ which reflects the amide character of these bonds. The carbamidoxime groups are in the $Z$-configuration.

Intramolecular resonance-assisted hydrogen bonding (RAHB) between the $\mathrm{H}$ atom of the HO-group and the $\mathrm{O}$ atom of the

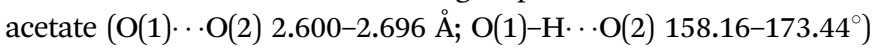
was identified and this hydrogen bonding can be responsible for additional stabilization of the structure with the monodentately coordinated amidoxime. Similar RAHB stabilized structures were reported for $(\mathrm{AcO}) \mathrm{M}^{\mathrm{II}}\left(\mathrm{M}=\mathrm{Mn},{ }^{31} \mathrm{Zn}^{30 b, 31} \mathrm{Ni}^{32}\right)$ complexes bearing bidentate $N, N^{\prime}$-coordinated 2-pyridine amidoxime.

Zinc(II) complexes with terminal $N$-coordinated amidoximes, are known, ${ }^{19}$ while the previously reported complexes comprise bidentately coordinated ligands in which at least one coordinating group is an $N$-coordinated amidoxime moiety (Fig. 4, C) ${ }^{1 a, 19,30 b, c, 31,33}$

Our complexes 2a-d are the first examples of $\mathrm{Zn}^{\mathrm{II}}$-complexes bearing monodentately $\mathrm{N}$-coordinated amidoxime, but one should take into account that this binding mode is rather specific as it is supported by RAHB (Fig. 4, D). 


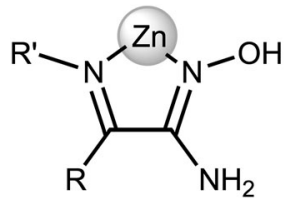

C

Fig. $4 \quad \mathrm{~N}$-Coordinated amidoxime moiety.

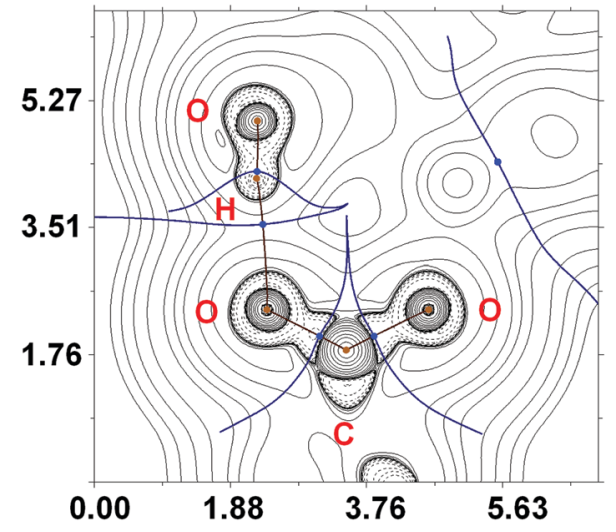

Fig. 5 Contour line diagram of the Laplacian distribution $\nabla^{2} \rho(\mathbf{r})$, bond paths and selected zero-flux surfaces for RAHB O-H..O in 2a. Bond critical points $(3,-1)$ are shown in blue and nuclear critical points $(3,-3)$ in pale brown, length unit - $\AA$.

The topological analysis of the electron density distribution within the formalism of Bader's theory (QTAIM method) ${ }^{34}$ for 2a-c (this approach has already been successfully used by us in studies of the non-covalent interactions and properties of coordination bonds in various transition metal complexes ${ }^{22,35}$ ) demonstrates the presence of appropriate bond critical points (BCPs) $(3,-1)$ for intramolecular RAHB O-H $\cdots \mathrm{O}$ in 2a-c (Fig. 5). The low magnitude of the electron density, positive values of the Laplacian, and zero or close to zero positive energy density in these BCPs are typical for hydrogen bonding (Table S3, ESI $\dagger$ ). The balance between the Lagrangian kinetic energy $G(\mathbf{r})$ and potential energy density $V(\mathbf{r})$ at these BCPs $(-G(\mathbf{r}) / V(\mathbf{r}) \geq 1)$ reveals the purely non-covalent nature of these interactions. The strength of $\mathrm{O}-\mathrm{H} \cdots \mathrm{O}$ contacts $\left(7.3-11.9 \mathrm{kcal} \mathrm{mol}^{-1}\right)$ corresponds to moderate hydrogen bonds following the classification

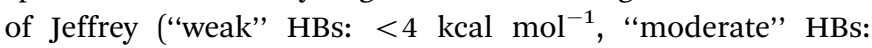
15-4 kcal mol ${ }^{-1}$, "strong" HBs: $\left.40-15 \mathrm{kcal} \mathrm{mol}^{-1}\right) .{ }^{36}$ The negligible values of the Wiberg bond indices for these contacts (0.01-0.04) computed by using the natural bond orbital (NBO) partitioning scheme additionally confirm the electrostatic nature of these non-covalent interactions. The electron-density delocalization in RAHB-involved 7-membered quasi-heterocyclic fragments in 2a-c has been estimated by the analysis of Wiberg bond indices (WI) for appropriate contacts (Table S4, ESI $\dagger$ ). The WI for O-C and $\mathrm{C}=\mathrm{O}$ contacts in $\mathbf{2 a - c}(1.29-1.55)$ indicate that these bonds are significantly involved in the conjugation. For more detailed information about our DFT calculations see the ESI. $\dagger$

(iii) The structures of the coupling products. In the molecular structures of $[\mathbf{4 b}(\mathrm{OTf})(\mathrm{EtOH})](\mathrm{OTf})$ and $\left[\mathbf{4 c}(\mathrm{OTf})_{2}\right]$, the coordination

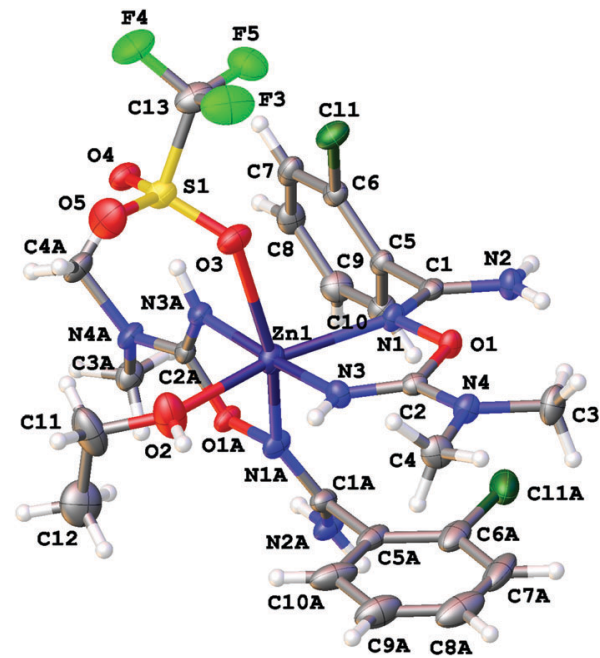

Fig. 6 Molecular structure of $[\mathbf{4 b}(\mathrm{OTf})(\mathrm{EtOH})](\mathrm{OTf})$ showing the atomic numbering scheme. Thermal ellipsoids are given at the $50 \%$ probability level.

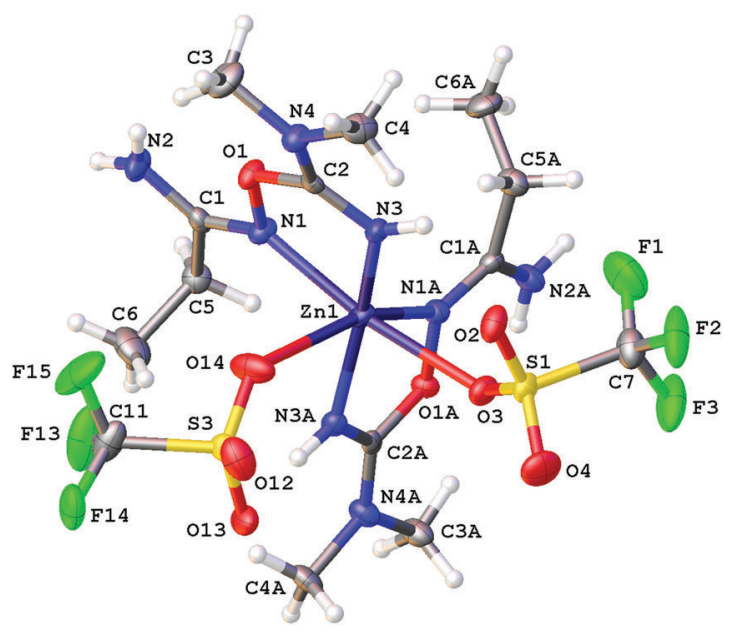

Fig. 7 Molecular structure of $\left[\mathbf{4 c}(\mathrm{OTf})_{2}\right]$ showing the atomic numbering scheme. Thermal ellipsoids are given at the $50 \%$ probability level.

polyhedra of the zinc(II) complexes display a typical distorted octahedral geometry (Fig. 6 and 7). All bond angles around the zinc(II) centers range from $75.44(10)$ to $119.93(16)^{\circ}$. The $\mathrm{Zn}-\mathrm{N}(1)$ bond lengths $[2.079(4)-2.121(3) \AA]$ exhibit values characteristic for (oxime) $\mathrm{Zn}^{\mathrm{II}}$ bonds, ${ }^{30 a}$ whereas the $\mathrm{Zn}-\mathrm{N}(3)$ distances $[1.944(4)-1.961(3) \AA]$ are usual for (imine) $\mathrm{Zn}^{\mathrm{II}}$ complexes. ${ }^{30 a}$ The $\mathrm{Zn}-\mathrm{O}(2)$ bond lengths $[2.507(4)-2.597(4) \AA]$ are longer than the normal single bonds thus indicating their ionic character, ${ }^{30 a}$ the $\mathrm{N}(2)-\mathrm{C}(1)$ [1.317(7)-1.336(4) ̊], $\mathrm{N}(4)-\mathrm{C}(2)$ [1.330(6)-1.349(6) ̊], and $\mathrm{N}(4)-\mathrm{C}(3 / 4)[1.454(6)-1.466(4) \AA]$ bonds are typical single bonds. ${ }^{23}$ The $\mathrm{N}(1)-\mathrm{C}(1)$ distances and the $\mathrm{N}(3)-\mathrm{C}(2)$ bond lengths [1.296(4)-1.309(4) ̊] indicate an intermediate order between typical single and double bonds, ${ }^{23}$ which reflects the amide character of these bonds. The $\mathrm{O}(1)-\mathrm{N}(1)$ distances [1.438(5)1.451(3) $\AA]$ are longer than usual $\mathrm{O}-\mathrm{N}^{\mathrm{sp}^{2}}$ bonds, which is specific for $O$-imidoylamidoximes. ${ }^{1 a}$ The carbamidoxime groups of both complexes are in the $Z$-configuration. In the crystal structures of 


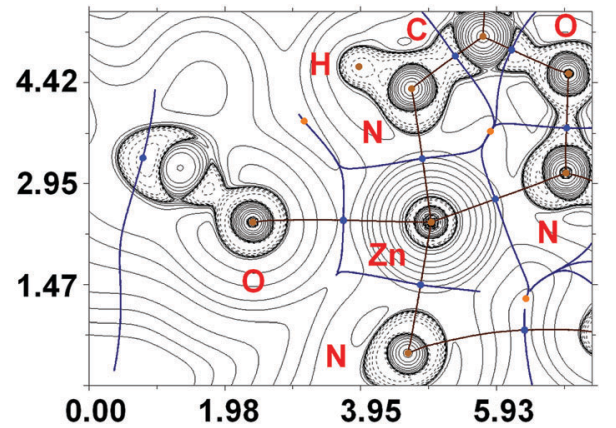

Fig. 8 Contour line diagram of the Laplacian distribution $\nabla^{2} \rho(\mathbf{r})$, bond paths and selected zero-flux surfaces for contacts $\mathrm{Zn}-\mathrm{O}$ and $\mathrm{Zn}-\mathrm{N}$ in $\left[\mathbf{4 c}(\mathrm{OTf})_{2}\right]$. Bond critical points $(3,-1)$ are shown in blue, nuclear critical points $(3,-3)$ in pale brown, and ring critical points $(3,+1)$ in orange, length unit $-\AA$.

$[\mathbf{4 b}(\mathrm{OTf})(\mathrm{EtOH})](\mathrm{OTf})$ and $\left[\mathbf{4 c}(\mathrm{OTf})_{2}\right]$, hydrogen bonds between the amide $\mathrm{H}$ atoms and the triflate $\mathrm{O}$ atoms were observed. The structure of $[\mathbf{4 b}(\mathrm{OTf})(\mathrm{EtOH})](\mathrm{OTf})$ includes one coordinated EtOH molecule that can be derived from the zinc(II)-mediated cleavage of EtOAc. This additionally confirms the occurrence of the $\mathrm{Zn}^{\mathrm{II}}$-mediated hydrolysis of EtOAc giving $\mathrm{AcOH}$ and EtOH.

In $\left[\mathbf{4 c}(\mathrm{OTf})_{2}\right]$, the QTAIM analysis reveals the presence of two BCPs for $\mathrm{Zn}-\mathrm{O}$ and four BCPs for $\mathrm{Zn}-\mathrm{N}$ contacts (Fig. 8). The properties of electron density in BCPs for $\mathrm{Zn}-\mathrm{N}$ contacts are typical for ordinary coordination bonds (the $\rho(\mathbf{r})$ and $\nabla^{2} \rho(\mathbf{r})$ values are positive and relatively high; the $\mathrm{H}_{\mathrm{b}}$ values are significantly negative; the $-G(\mathbf{r}) / V(\mathbf{r}) \ll 1$; Wiberg bond indices for these contacts are noticeable), whereas $\mathrm{Zn}-\mathrm{O}$ contacts can be classified as noncovalent close shell interactions with some contribution of the covalent component (for more detailed information see the ESI $\dagger$ ).

(iv) The structures of the $O$-iminoacylated oximes. The structures are similar to those reported previously ${ }^{1 a, 18}$ and a detailed description of the molecular structures of [5a](OTf) and $[\mathbf{5 d}](\mathrm{OTf})$ is given in the ESI. $\dagger$

\section{Zinc(II)-mediated generation of 1,2,4-oxadiazoles from amidoximes and nitriles}

In this work, we succeeded in isolating and identifying zinc(II) complexes featuring amidoximes and aminonitrones and studied the reaction of these (amidoxime/aminonitrone) $\mathrm{Zn}^{\mathrm{II}}$ complexes with $\mathrm{Me}_{2} \mathrm{NCN}$. All accumulated data combined with those from our previous study ${ }^{18}$ on metal-free heterocyclization of amidinium salts $[\mathbf{5}]^{+}$allowed the formulation of the detailed mechanism of zinc(II)-mediated generation of 1,2,4-oxadiazoles from amidoximes and nitriles that efficiently proceeds in undried ethyl acetate.

Firstly, complexes 2a-d are formed via coordination of both an amidoxime and $\mathrm{AcO}^{-}$to the zinc(II) center (Scheme 3, b3 and d3). Acetate is generated via the zinc(II)-mediated hydrolysis of EtOAc and this explains why the reaction occurs so easily namely in ethyl acetate (c3). Amidoxime complexes 2a-d are inactive toward dimethylcyanamide, whereas aminonitrone complexes $[\mathbf{3 a}-\mathbf{d}]^{4+}$ - which are formed from $\mathbf{2 a - d}$ with excess zinc(II) (e3 and f3)-react with $\mathrm{Me}_{2} \mathrm{NCN}$ giving imino

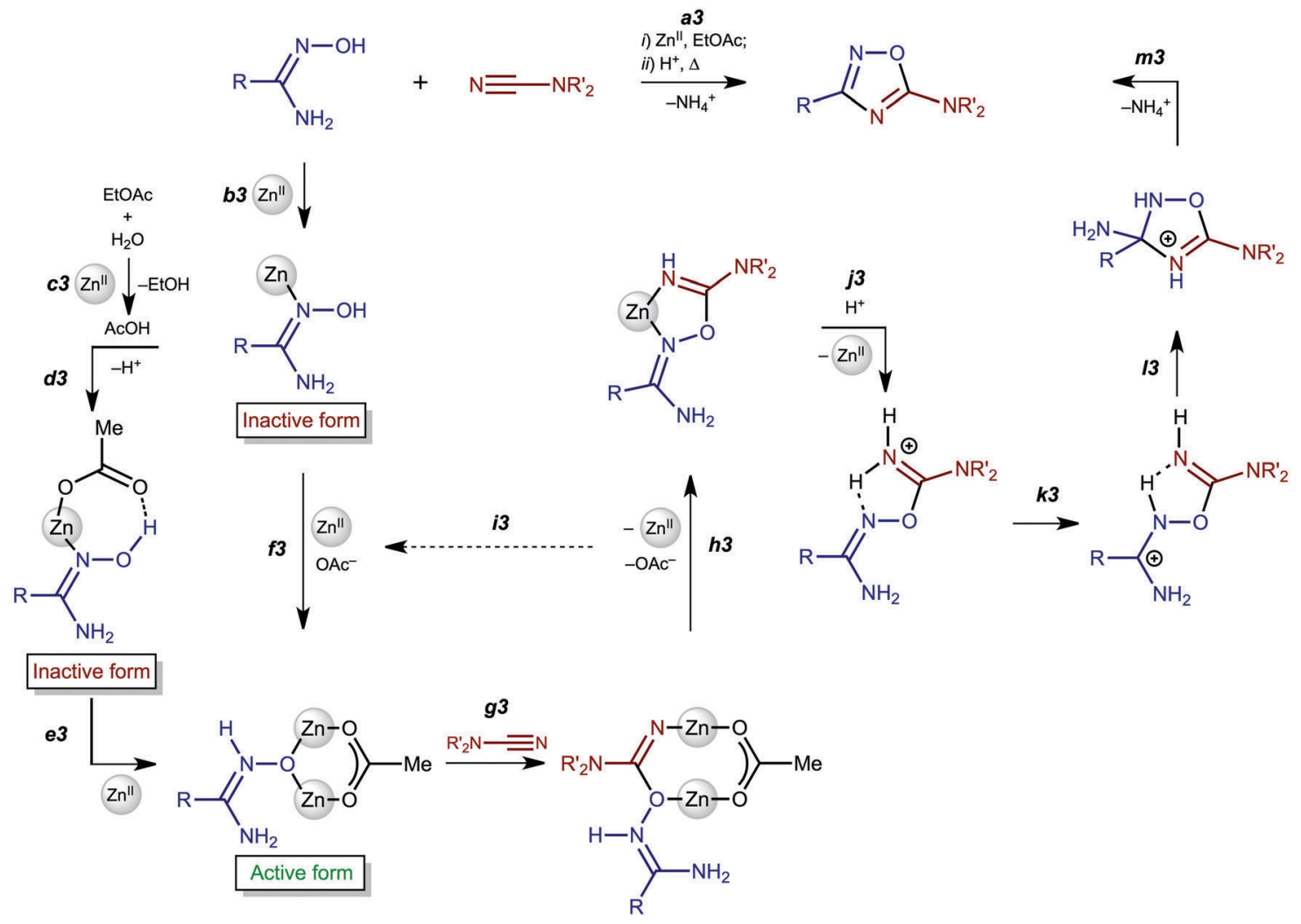

Scheme 3 Mechanism of the zinc(॥)-mediated generation of 1,2,4-oxadiazoles from amidoximes and nitriles. 
species $[\mathbf{4 a}-\mathbf{c}]^{2+}(\mathrm{g} 3$ and $\mathrm{h} 3)$. This observation agrees well with the theoretical calculation data indicating that the nucleophilic addition of amidoximes to electrophilically activated $\mathrm{C} \equiv \mathrm{N}^{22}$ and $\mathrm{C}=\mathrm{C}^{37}$ bonds proceeds specifically via the aminonitrone form.

Addition of a strong acid ( $\mathrm{TfOH}$ or $p-\mathrm{TolSO}_{3} \mathrm{H}$ ) leads to the decoordination and liberation of amidinium salts $[\mathbf{5 a - d}]^{+}(\mathrm{j} 3)$. In the case of the ${ }^{t} \mathrm{BuC}\left(\mathrm{NH}_{2}\right)=\mathrm{NOH}$ derivative, whose $N$-coordination to the zinc(II) (h3) is sterically hindered, liberation of $[\mathbf{5 d}]^{+}$(j3) occurs even in the absence of an acid. Amidinium salts $[\mathbf{5 a}-\mathbf{d}]^{+}$undergo prototropic tautomerization to $O$-iminoacyl amidinium species $(\mathrm{k} 3)$. For $\left[\mathrm{RC}\left(\mathrm{NH}_{2}\right)=\mathrm{NOC}\left(\mathrm{R}^{\prime \prime}\right)=\mathrm{NH}_{2}\right]^{+}$, this step is accelerated by donor $\mathrm{R}$ and acceptor $\mathrm{R}^{\prime \prime}$ substituents. Accordingly, derivatives of conventional nitriles $\left(\mathrm{R}^{\prime \prime}=\right.$ Alk or $\left.\mathrm{Ar}\right)$ are significantly less stable than dialkylcyanamide derivatives $\left(\mathrm{R}^{\prime \prime}=\mathrm{NR}_{2}{ }^{\prime}\right.$ with strong $+M$ effect). Tautomerization (k3) followed by the intramolecular nucleophilic attack of the imine $\mathrm{N}$ atom on the electrophilically activated $\mathrm{C}$ atom leads to 3-amino-1,2,4-oxadiazoline (13). The latter compound is subject to aromatization accompanied by the elimination of $\mathrm{NH}_{4}{ }^{+}$giving 1,2,4-oxadiazoles (m3).

\section{Concluding remarks}

In this work, we succeeded in generating, isolating, and fully characterizing the trinuclear zinc(II) species [3a-d] (OTf) ${ }_{4}$, which most likely serve as key intermediates in the $\mathrm{Zn}^{\mathrm{II}}$-mediated generation of 1,2,4-oxadiazoles from amidoximes and nitriles in EtOAc. ${ }^{1 a, 18}$ The amidoxime ligands in $[\mathbf{3 a - d}](\mathrm{OTf})_{4}$ are stabilized in their aminonitrone form, $\mathrm{RC}\left(\mathrm{NH}_{2}\right)=\mathrm{N}^{+}(\mathrm{H}) \mathrm{O}^{-}$, and they act as $\mu_{2}$-ligands being coordinated through the $\mathrm{O}$ atom. Before our experiments, this type of coordination was unknown for amidoxime zinc(II) complexes and this ligation pattern was observed only at a molybdenum(vi) center. ${ }^{19,28}$

All accumulated reactivity data, combined with those from our previous study ${ }^{18}$ on metal-free heterocyclization of amidinium salts $[5]^{+}$, allowed the formulation of the detailed mechanism of the zinc(II)-mediated generation of 1,2,4-oxadiazoles from amidoximes and nitriles and the explanation of the effect of undried ethyl acetate on facilitation of the heterocyclization (Scheme 3). It is now clear that the overall reaction consists of four main steps namely the acetate-promoted formation of the trinuclear complexes, amidoxime-nitrile coupling, acid driven decoordination, and, eventually, the heterocyclization. All these data allowed the rational choice of the reactants and further tuning of the reaction conditions. It is noteworthy that although for a while we are satisfied with improving the synthesis of 1,2,4-oxadiazoles with stoichiometric amounts of zinc(II), our distant goal is to find out a catalytic system for the preparation of 1,2,4-oxadiazoles and we are currently testing appropriate catalytic systems.

One more issue requires additional attention. Zinc(II) centers belong to the category of kinetically labile metal centers when ambidentate or, in general, ligands with multiple donor centers are subject to facile linkage isomerization giving various coordination pattern species. In this respect, the different reactivity of $\mathbf{2 a - d}$ and $[3 \mathbf{3 a}-\mathbf{d}](\mathrm{OTf})_{4}$ toward the coupling with $\mathrm{Me}_{2} \mathrm{NCN}$ is surprising. The observed high reactivity of the trinuclear complexes can be further explored in at least two directions: (i) nitrones, as allyl anion type dipoles, are involved in cycloaddition reactions with various dipolarophiles. ${ }^{38}$ Although amidoximes exist in tautomeric equilibrium with their aminonitrone form $\mathrm{RC}\left(\mathrm{NH}_{2}\right)=\mathrm{N}^{+}(\mathrm{H}) \mathrm{O}^{-}$, aminonitrone reactivity (e.g. toward cycloaddition) has never been observed in the past. The obtained aminonitrone trinuclear complexes represent available reactants for the inverse electron demand cycloaddition (type III in Sustman's classification ${ }^{39}$ ), when the reaction involves complexed dipole and uncoordinated dipolarophile; (ii) many organic reactions involving polynuclear metal species proceed via simultaneous coordination of two reactants to the adjacent metal centers, which, via the so-called "two-metal-mechanism", ${ }^{40}$ couples intramolecularly. One can assume that substrates with donor centers could split the $\left[\mathrm{Zn}^{\mathrm{II}}\right]_{2}\left\{\mu_{2}-\mathrm{ON}(\mathrm{H})=\mathrm{C}\left(\mathrm{NR}_{2}\right) \mathrm{R}^{\prime}\right\}$ bridge by their ligation to a zinc(II) center followed by intramolecular coupling with aminonitrones leading to novel organic species. All works in these two directions are underway in our group.

\section{Experimental section}

\section{Materials and instrumentation}

Solvents were obtained from commercial sources and used as received. All of the syntheses were conducted in an air atmosphere. Amidoximes 1a-d were synthesized according to the literature methods. ${ }^{1 a}$ Melting points were measured on a Stuart SMP30 apparatus in capillaries and were not corrected. Microanalyses (C, H, N) were carried out on a Euro EA3028-HT instrument. Electrospray ionization mass-spectra were obtained on a Bruker micrOTOF spectrometer equipped with an electrospray ionization (ESI) source. The instrument was operated both in negative and positive ion modes in the $m / z$ range 50-3000. The nebulizer gas flow was 0.4 bar and the drying gas flow was $4.0 \mathrm{~L} \mathrm{~min}^{-1}$. For HRESI, complexes were dissolved in $\mathrm{MeOH}$. In the isotopic pattern, the most intensive peak is reported. Infrared spectra (4000-400 $\mathrm{cm}^{-1}$ ) were recorded on a Shimadzu IR Prestige-21 instrument in $\mathrm{KBr}$ pellets. ${ }^{1} \mathrm{H}$ and ${ }^{13} \mathrm{C}\left\{{ }^{1} \mathrm{H}\right\}$ NMR spectra were measured on a Bruker Avance 400 at ambient temperature; residual solvent signals were used as the internal standard. Solid state CP-MAS TOSS ${ }^{13} \mathrm{C}\left\{{ }^{1} \mathrm{H}\right\}$ NMR spectra were measured on Bruker Avance III WB 400 with the magic angle spinning at $6 \mathrm{kHz}$ frequency.

\section{X-ray structure determination}

The single-crystal X-ray diffraction experiment was carried out using Agilent Technologies "Xcalibur" and "Supernova" diffractometers with monochromated $\mathrm{MoK} \alpha$ or $\mathrm{CuK} \alpha$ radiation, respectively. The crystal was fixed on a micro mount, placed on the diffractometer and measured at a temperature of $100 \mathrm{~K}$. The unit cell parameters and other summarized data are represented in Tables $1 \mathrm{~S}$ and $2 \mathrm{~S}$ (ESI $\dagger$ ). The structure has been solved by using the Superflip ${ }^{41}$ structure solution program using charge flipping and refined using the ShelXL ${ }^{42}$ refinement 
incorporated in the OLEX2 program package. ${ }^{43}$ The hydrogen atoms were placed in calculated positions and were included in the refinement in the 'riding' model approximation. Empirical absorption correction was applied in the CrysAlisPro ${ }^{44}$ program complex using spherical harmonics, implemented in SCALE3 ABSPACK scaling algorithm. CCDC 1503999-1504006.

\section{Computational details}

The single point calculations based on the experimental X-ray geometries (quasi-solid-state approach) have been carried out at the DFT level of theory using the M06-2X functional ${ }^{34}$ (this functional was specifically developed to describe weak dispersion forces and non-covalent interactions) with the help of Gaussian- $09^{45}$ program package. The standard $6-311+\mathrm{G}(\mathrm{d}, \mathrm{p})$ basis sets have been used for all atoms. The topological analysis of the electron density distribution with the help of the atomsin-molecules (QTAIM) method developed by Bader ${ }^{34}$ has been performed by using the Multiwfn program (version 3.3.7). ${ }^{46}$ The Wiberg bond indices (WI) were computed by using the natural bond orbital (NBO) partitioning scheme. ${ }^{47}$ The Cartesian atomic coordinates of model structures are presented in ESI, $\dagger$ Table S5.

\section{Syntheses and characterization}

Preparation of $2 \mathbf{a}-\mathbf{d}$. Powders of $1 \mathbf{a}-\mathbf{d}(1 \mathrm{mmol})$ were added to a solution of $\mathrm{Zn}(\mathrm{OAc})_{2} \cdot 2 \mathrm{H}_{2} \mathrm{O}(109.8 \mathrm{mg} ; 0.5 \mathrm{mmol})$ in acetone $(6 \mathrm{~mL})$ placed in a $10 \mathrm{~mL}$ round-bottomed flask. The solution was stirred for $5 \mathrm{~min}$ at $50{ }^{\circ} \mathrm{C}$, and then evaporated in vacuo at $50{ }^{\circ} \mathrm{C}$. An oily residue was crystallized under chloroform $(1.5 \mathrm{~mL})$ with ultrasound treatment. The resulting precipitate was filtered off, and dried in air at $50{ }^{\circ} \mathrm{C}$.

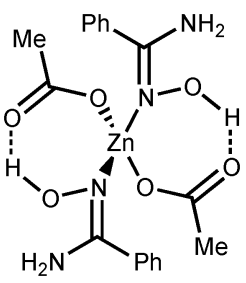

2a. Yield: $80 \%$ (182.3 mg). Mp: $145{ }^{\circ} \mathrm{C}$ (dec.). Anal. calcd for $\mathrm{C}_{18} \mathrm{H}_{22} \mathrm{~N}_{4} \mathrm{O}_{6} \mathrm{Zn}: \mathrm{C}, 47.43 ; \mathrm{H}, 4.87 ; \mathrm{N}, 12.29$. Found: $\mathrm{C}, 47.88$; $\mathrm{H}, \quad 4.75 ; \mathrm{N}$, 12.28. HRESI $^{+}-\mathrm{MS}$ (MeOH, $\left.m / z\right): 259.0059$ $\left(\left[\mathrm{M}-\mathrm{PhC}\left(\mathrm{NH}_{2}\right)=\mathrm{NOH}-\mathrm{OAc}\right]^{+}, \quad\right.$ calcd 259.0056), 335.0469 $\left([\mathrm{M}-2 \mathrm{OAc}-\mathrm{H}]^{+}\right.$, calcd 335.0481), $382.9346\left(\left[\mathrm{M}+\mathrm{Zn}-\mathrm{PhC}\left(\mathrm{NH}_{2}\right)=\right.\right.$ $\mathrm{NOH}-\mathrm{H}]^{+}$, calcd 382.9372), $458.9771\left([\mathrm{M}+\mathrm{Zn}-\mathrm{OAc}-2 \mathrm{H}]^{+}\right.$, calcd 458.9798), $518.9991\left([\mathrm{M}+\mathrm{Zn}-\mathrm{H}]^{+}\right.$, calcd 519.0001), 579.0156 $\left([\mathrm{M}+\mathrm{Zn}+\mathrm{OAc}]^{+}\right.$, calcd 579.0222). $\mathrm{HRESI}^{-}$-MS $(\mathrm{m} / \mathrm{z}): 240.9730$ ([Zn(OAc) $\left.]_{3}\right]^{-}$, calcd 240.9685), $424.9288\left(\left[\mathrm{Zn}_{2}(\mathrm{OAc})_{5}\right]^{-}\right.$, calcd 424.9213). IR ( $\mathrm{KBr}$, selected bands, $\left.\mathrm{cm}^{-1}\right): 3464(\mathrm{~s}), 3318(\mathrm{~s})$, $3178(\mathrm{~m}) \quad \nu(\mathrm{N}-\mathrm{H}) ; \quad 3060 \quad(\mathrm{~m}), \quad 2876(\mathrm{w}-\mathrm{m}) \quad \nu(\mathrm{C}-\mathrm{H}) ; \quad 1662(\mathrm{vs})$ $\nu(\mathrm{C}=\mathrm{N}) ; 1564(\mathrm{vs}), 1420(\mathrm{vs}), 1340(\mathrm{~s}) \nu(\mathrm{C}=\mathrm{O}) .{ }^{1} \mathrm{H}$ NMR $\left(\left(\mathrm{CD}_{3}\right)_{2} \mathrm{CO}\right.$, $\delta): 7.64(\mathrm{~d}, \mathrm{br}, 2 \mathrm{H}, o-\mathrm{CH}), 7.46-7.38(\mathrm{~m}, 3 \mathrm{H}, p-\mathrm{CH}$ and $m-\mathrm{CH})$, 5.92 (s, br, 2H, $\mathrm{NH}_{2}$ ), 1.91 (s, 3H, CH $)$. CP-MAS TOSS ${ }^{13} \mathrm{C}\left\{{ }^{1} \mathrm{H}\right\}$ NMR $(\delta)$ : 180.23, $178.18\left(\mathrm{CH}_{3} \mathrm{CO}_{2}\right) ; 158.59(C=\mathrm{N}) ; 132.73$, 130.56, 128.23, 126.98, 126.15 (Ar); 24.03, $22.03\left(\mathrm{CH}_{3}\right)$. Crystals of 2a suitable for X-ray diffraction were obtained by slow evaporation of $\mathrm{Me}_{2} \mathrm{CO}$ solution at RT in air.

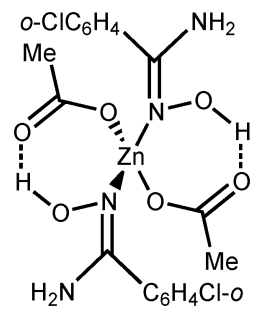

2b. Yield: $82 \%$ (215.1 mg). Mp: $177{ }^{\circ} \mathrm{C}$ (dec.). Anal. calcd for $\mathrm{C}_{18} \mathrm{H}_{20} \mathrm{~N}_{4} \mathrm{Cl}_{2} \mathrm{O}_{6} \mathrm{Zn}$ : C, 41.21; H, 3.84; N, 10.68. Found: C, 40.95; H, 3.61; N, 10.81. HRESI $^{+}$-MS (MeOH, $\left.m / z\right): 292.9671$ $\left(\left[\mathrm{M}-\mathrm{ClC}_{6} \mathrm{H}_{4} \mathrm{C}\left(\mathrm{NH}_{2}\right)=\mathrm{NOH}-\mathrm{OAc}\right]^{+}\right.$, calcd 292.9666), 404.9651 ([M-2OAc-H $]^{+}$, calcd 404.9672), $528.8963\left([\mathrm{M}+\mathrm{Zn}-\mathrm{OAc}-2 \mathrm{H}]^{+}\right.$, calcd 528.8997), 588.9170 ([M $+\mathrm{Zn}-\mathrm{H}]^{+}$, calcd 588.9209), $648.9371\left(\left[\mathrm{M}+\mathrm{Zn}+\mathrm{OAc}^{+}\right.\right.$, calcd 648.9421). $\mathrm{HRESI}^{-}-\mathrm{MS}(\mathrm{m} / \mathrm{z})$ : $240.9745\left(\left[\mathrm{Zn}(\mathrm{OAc})_{3}\right]^{-}\right.$, calcd 240.9685), $424.9309\left(\left[\mathrm{Zn}_{2}(\mathrm{OAc})_{5}\right]^{-}\right.$, calcd 424.9213). IR ( $\mathrm{KBr}$, selected bands, $\mathrm{cm}^{-1}$ ): 3498(s), 3406(s), 3362(s), 3202(m-s) $\nu(\mathrm{N}-\mathrm{H}) ; 3078(\mathrm{~m}-\mathrm{s}), 2832(\mathrm{~s}) \nu(\mathrm{C}-\mathrm{H}) ; 1662(\mathrm{vs})$ $\nu(\mathrm{C}=\mathrm{N}) ; 1574(\mathrm{vs}), 1402(\mathrm{vs}), 1340(\mathrm{~s}) \nu(\mathrm{C}=\mathrm{O}) .{ }^{1} \mathrm{H}$ NMR $\left(\left(\mathrm{CD}_{3}\right)_{2} \mathrm{CO}\right.$, $\delta): 7.50-7.43(\mathrm{~m}, 3 \mathrm{H}, \mathrm{CH}), 7.40-7.36(\mathrm{~m}, 1 \mathrm{H}, \mathrm{CH}), 6.27$ (s, br, 2H, $\left.\mathrm{NH}_{2}\right), 1.78\left(\mathrm{~s}, 3 \mathrm{H}, \mathrm{CH}_{3}\right)$. CP-MAS TOSS ${ }^{13} \mathrm{C}$ NMR $(\delta):$ 176.94, $175.69\left(\mathrm{CH}_{3} \mathrm{CO}_{2}\right) ; 155.53,153.57(\mathrm{C}=\mathrm{N}) ; 135.27,132.56,130.67$, 127.51, $126.48(\mathrm{Ar}) ; 22.94,20.36\left(\mathrm{CH}_{3}\right)$. Crystals of $2 \mathbf{b}$ suitable for X-ray diffraction were obtained by slow evaporation of $\mathrm{Me}_{2} \mathrm{CO}$ solution at RT in air.

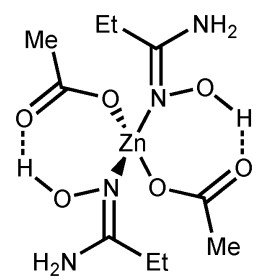

2c. Yield: $75 \%$ (134.9 mg). Mp: $158{ }^{\circ} \mathrm{C}$ (dec.). Anal. calcd for $\mathrm{C}_{10} \mathrm{H}_{22} \mathrm{~N}_{4} \mathrm{O}_{6} \mathrm{Zn}: \mathrm{C}, 33.39 ; \mathrm{H}, 6.16 ; \mathrm{N}, 15.58$. Found: $\mathrm{C}, 33.20 ; \mathrm{H}$, 6.07; N, 15.37. HRESI $^{+}-\mathrm{MS}(\mathrm{MeOH}, \mathrm{m} / \mathrm{z}): 239.0464$ ([M-2OAc-H $]^{+}$, calcd 239.0481), $334.9346\left(\left[\mathrm{M}+\mathrm{Zn}-\mathrm{EtC}\left(\mathrm{NH}_{2}\right)=\mathrm{NOH}-\mathrm{H}\right]^{+}\right.$, calcd 334.9372), 362.9748 ([M + Zn-OAc-2H $]^{+}$, calcd 362.9797), $422.9979\left([\mathrm{M}+\mathrm{Zn}-\mathrm{H}]^{+}\right.$, calcd 423.0009), $483.0190\left([\mathrm{M}+\mathrm{Zn}+\mathrm{OAc}]^{+}\right.$, calcd 483.0221). HRESI $^{-}$-MS $(\mathrm{m} / \mathrm{z}): 240.9729$ ([Zn(OAc) $\left.)_{3}\right]^{-}$, calcd 240.9685), $424.9282\left(\left[\mathrm{Zn}_{2}(\mathrm{OAc})_{5}\right]^{-}\right.$, calcd 424.9213). IR (KBr, selected bands, $\left.\mathrm{cm}^{-1}\right)$ : 3484(s), 3428(s), 3344(s-vs), 3218(s) $\nu(\mathrm{N}-\mathrm{H}) ; 3088(\mathrm{~m})$, 2990(s), 2880(m-s), 2772(m) $\nu(\mathrm{C}-\mathrm{H}) ; 1672(\mathrm{vs}) \nu(\mathrm{C}=\mathrm{N}) ; 1562(\mathrm{vs})$, 1412(vs), 1346(vs) $\nu(\mathrm{C}=\mathrm{O}) .{ }^{1} \mathrm{H}$ NMR $\left(\left(\mathrm{CD}_{3}\right)_{2} \mathrm{CO}, \delta\right): 6.40$ (s, br, $2 \mathrm{H}$, $\mathrm{NH}_{2}$ ), 2.30 (q, 2H, $\mathrm{CH}_{2}$ ), $1.92\left(\mathrm{~s}, 3 \mathrm{H}, \mathrm{CH}_{3}\right), 1.16$ (t, 3H, $\left.\mathrm{CH}_{3}\right)$. CP-MAS TOSS ${ }^{13} \mathrm{C}\left\{{ }^{1} \mathrm{H}\right\} \operatorname{NMR}(\delta): 182.47,178.12\left(\mathrm{CH}_{3} \mathrm{CO}_{2}\right) ; 160.93(C=\mathrm{N})$;<smiles>CC(=O)O[Z10]1(N=C(N)C(C)(C)C)O[CH]OPON1C(C)=O</smiles> 
$25.41\left(\mathrm{CH}_{2} \mathrm{CH}_{3}\right) ; 22.98,21.56\left(\mathrm{CH}_{3} \mathrm{CO}_{2}\right) ; 12.85,11.43\left(\mathrm{CH}_{2} \mathrm{CH}_{3}\right)$. Crystals of $2 \mathrm{c}$ suitable for X-ray diffraction were obtained by slow evaporation of $\mathrm{Me}_{2} \mathrm{CO}$ solution at RT in air.

2d. Yield: $78 \%$ (162.2 mg). Mp: $98{ }^{\circ} \mathrm{C}$ (dec.). Anal. calcd for $\mathrm{C}_{14} \mathrm{H}_{30} \mathrm{~N}_{4} \mathrm{O}_{6} \mathrm{Zn}$ : C, 40.44; H, 7.27; N, 13.47. Found: C, 40.54; H, 7.19; $\mathrm{N}, 13.69$. HRESI $^{+}-\mathrm{MS}(\mathrm{MeOH}, m / z): 239.0439\left(\left[\mathrm{M}-{ }^{t} \mathrm{Bu}\left(\mathrm{NH}_{2}\right)=\mathrm{NOH}-\right.\right.$ $\mathrm{OAc}^{+}$, calcd 239.0369), 295.1099 ([M-2OAc-H $]^{+}$, calcd 295.1107), $419.0406\left([\mathrm{M}+\mathrm{Zn}-\mathrm{OAc}-2 \mathrm{H}]^{+}\right.$, calcd 419.0423), 479.0717 $\left([\mathrm{M}+\mathrm{Zn}-\mathrm{H}]^{+}\right.$, calcd 479.0831), $539.0819\left([\mathrm{M}+\mathrm{Zn}+\mathrm{OAc}]^{+}\right.$, calcd 539.0847). HRESI $^{-}$-MS $(\mathrm{m} / \mathrm{z}): 240.9727 \quad\left(\left[\mathrm{Zn}(\mathrm{OAc})_{3}\right]^{-}\right.$, calcd 240.9685), $424.9351\left(\left[\mathrm{Zn}_{2}(\mathrm{OAc})_{5}\right]^{-}\right.$, calcd 424.9213). IR $(\mathrm{KBr}$, selected bands, $\left.\mathrm{cm}^{-1}\right)$ : 3434(s), 3302(s), 3164(m-s) $\nu(\mathrm{N}-\mathrm{H})$; 2976(s) $\nu(\mathrm{C}-\mathrm{H}) ; 1668(\mathrm{vs}) \nu(\mathrm{C}=\mathrm{N}) ; 1608(\mathrm{vs}), 1498(\mathrm{~s}), 1396(\mathrm{vs})$ $\nu(\mathrm{C}=\mathrm{O}) .{ }^{1} \mathrm{H}$ NMR $\left(\left(\mathrm{CD}_{3}\right)_{2} \mathrm{CO}, \delta\right): 5.29$ (s, br, $\left.2 \mathrm{H}, \mathrm{NH}_{2}\right), 1.97$ (s, 3H, $\left.\mathrm{CH}_{3}\right), 1.19$ (s, 9H, $\left.\mathrm{CH}_{3}\right)$. CP-MAS TOSS ${ }^{13} \mathrm{C}\left\{{ }^{1} \mathrm{H}\right\} \operatorname{NMR}(\delta)$ : $176.91 ; 176.40\left(\mathrm{CH}_{3} \mathrm{CO}_{2}\right) ; 160.93(\mathrm{C}=\mathrm{N})$; 33.87, $33.50\left(\mathrm{C}\left(\mathrm{CH}_{3}\right)_{3}\right)$; 27.27, $27.00\left(\mathrm{C}\left(\mathrm{CH}_{3}\right)_{3}\right) ; 23.47,22.89\left(\mathrm{CH}_{3} \mathrm{CO}_{2}\right)$.

Preparation of $[3 a-d](O T f)_{4}$. Route b2. Powders of 1a-d ( $1 \mathrm{mmol}$ ) were added to a stirred solution of the corresponding complexes 2a-d (0.5 mmol) and $\mathrm{Zn}(\mathrm{OTf})_{2}$ (363.52 $\left.\mathrm{mg} ; 1 \mathrm{mmol}\right)$ in acetone $(6 \mathrm{~mL})$ placed in a $10 \mathrm{~mL}$ round-bottomed flask. The solution was stirred for $5 \mathrm{~min}$ at $50{ }^{\circ} \mathrm{C}$, whereupon the solvent was evaporated in vacuo at $50{ }^{\circ} \mathrm{C}$. Route c2. Powders of $1 \mathrm{a}-\mathbf{d}$ $(2 \mathrm{mmol})$ were added to a stirred solution of $\mathrm{Zn}(\mathrm{OTf})_{2}(545.3 \mathrm{mg}$; $1.5 \mathrm{mmol})$ in ethyl acetate $(10 \mathrm{~mL})$ placed in a $25 \mathrm{~mL}$ roundbottomed flask. The solution was stirred for $30 \mathrm{~min}$ on reflux, and then the solvent was evaporated in vacuo at $50{ }^{\circ} \mathrm{C}$. For both routes, the oily residue that was formed was crystallized under chloroform $(1.5 \mathrm{~mL})$ with ultrasound treatment. The resulting precipitate was filtered off, and dried at $50{ }^{\circ} \mathrm{C}$ (route b2) or at $70{ }^{\circ} \mathrm{C}$ (route c) in air. The yields are given for route c. For route b2, the yields are $80-90 \%$ based on the corresponding $2 \mathbf{a}-\mathbf{d}$.

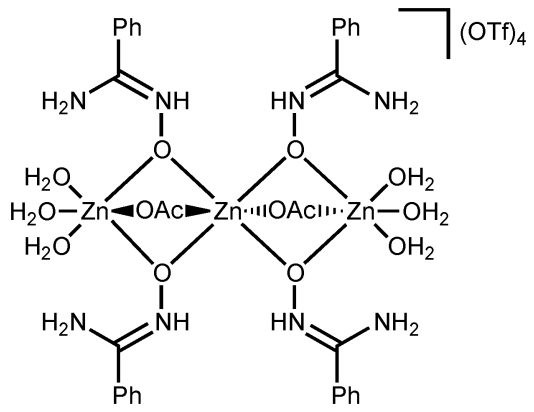

[3a](OTf) . Yield: $87 \%$ (680 mg). Mp: $116{ }^{\circ} \mathrm{C}$ (dec.). Anal. calcd for $\mathrm{C}_{36} \mathrm{H}_{50} \mathrm{~N}_{8} \mathrm{~F}_{12} \mathrm{O}_{26} \mathrm{~S}_{4} \mathrm{Zn}_{3}$ : C, 27.66; H, 3.22; N, 7.17. Found: C, 27.44; H, 2.99; N, 7.21. $\mathrm{HRESI}^{+}-\mathrm{MS}(\mathrm{MeOH}, \mathrm{m} / z)$ : $259.0067\left(\left[\mathrm{Zn}(\mathrm{OAc})\left(\mathrm{PhC}\left(\mathrm{NH}_{2}\right)=\mathrm{NOH}\right)\right]^{+}, \quad\right.$ calcd 259.0056), $335.0433\left(\left[\mathrm{Zn}\left(\mathrm{PhC}\left(\mathrm{NH}_{2}\right)=\mathrm{NOH}\right)-\mathrm{H}\right]^{+}\right.$, calcd 335.0481), 382.9308 $\left(\left[\mathrm{Zn}_{2}(\mathrm{OAc})_{2}\left(\mathrm{PhC}\left(\mathrm{NH}_{2}\right)=\mathrm{NOH}\right)-\mathrm{H}\right]^{+}\right.$, calcd 382.9372), 458.9737 $\left(\left[\mathrm{Zn}_{2}(\mathrm{OAc})\left(\mathrm{PhC}\left(\mathrm{NH}_{2}\right)=\mathrm{NOH}\right)_{2}-2 \mathrm{H}\right]^{+}\right.$, calcd 458.9798), 518.9933 $\left(\left[\mathrm{Zn}_{2}(\mathrm{OAc})_{2}\left(\mathrm{PhC}\left(\mathrm{NH}_{2}\right)=\mathrm{NOH}\right)_{2}-\mathrm{H}\right]^{+}\right.$, calcd 519.0001), 579.0156 $\left(\left[\mathrm{Zn}_{2}(\mathrm{OAc})_{3}\left(\mathrm{PhC}\left(\mathrm{NH}_{2}\right)=\mathrm{NOH}\right)_{2}\right]^{+}\right.$, calcd 579.0222). HRESI $^{-}$-MS $(\mathrm{m} / \mathrm{z}): 646.8494\left(\left[\mathrm{Zn}(\mathrm{OTf})_{3}\left(\mathrm{PhC}\left(\mathrm{NH}_{2}\right)=\mathrm{NOH}\right)\right]^{-}\right.$, calcd 646.8483), 862.7197 $\left(\left[\mathrm{Zn}_{2}(\mathrm{OTf})_{4}\left(\mathrm{PhC}\left(\mathrm{NH}_{2}\right)=\mathrm{NOH}\right)-\mathrm{H}\right]^{-}\right.$, calcd 862.7167). IR (KBr, selected bands, $\left.\mathrm{cm}^{-1}\right): 3412(\mathrm{~s}), 3216(\mathrm{~s}) \nu(\mathrm{O}-\mathrm{H})$ and $\nu(\mathrm{N}-\mathrm{H})$; 2968(w), 2868(w) $\nu(\mathrm{C}-\mathrm{H}) ; 1658(\mathrm{vs}) \nu(\mathrm{C}=\mathrm{N}) ; 1570(\mathrm{vs}), 1448(\mathrm{~s})$, 1404(s) $\nu(\mathrm{C}=\mathrm{O}) ; 1246(\mathrm{vs}), 1174(\mathrm{vs}) \nu(\mathrm{S}=\mathrm{O}) .{ }^{1} \mathrm{H}$ NMR $\left(\left(\mathrm{CD}_{3}\right)_{2} \mathrm{CO}\right.$, $\delta): 8.48\left(\mathrm{~s}, \mathrm{br}, 2 \mathrm{H}, \mathrm{NH}_{2}\right), 7.83(\mathrm{~m}, \mathrm{br}, 2 \mathrm{H}, o-\mathrm{CH}), 7.73(\mathrm{t}, \mathrm{br}, 1 \mathrm{H}$, $p$-CH), 7.62 (t, br, 2H, m-CH), 1.95 (s, 3H, CH $H_{3}$. CP-MAS TOSS ${ }^{13} \mathrm{C}\left\{{ }^{1} \mathrm{H}\right\}$ NMR $(\delta): 178.42\left(\mathrm{CH}_{3} C_{2}\right) ; 157.59(C=\mathrm{N}) ; 133.77$, 133.09, 131.54, 127.15, 124.37 (Ar); $119.12\left(\mathrm{CF}_{3}\right) ; 26.10\left(\mathrm{CH}_{3}\right)$. Crystals of $[3 a](O T f)_{4}$ suitable for X-ray diffraction were obtained by slow evaporation of $\mathrm{Me}_{2} \mathrm{CO}$ solution at RT in air.

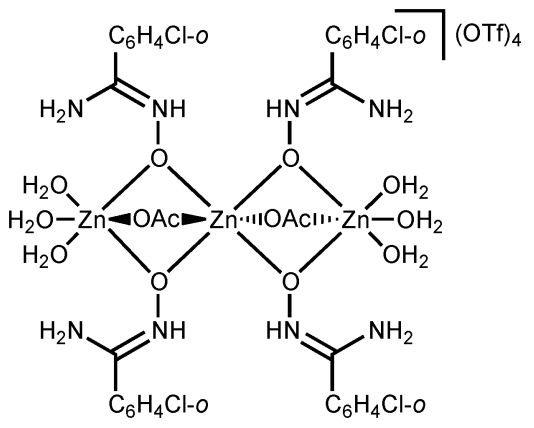

[3b](OTf) . Yield: $73 \%$ (620.9 mg). Mp: $119{ }^{\circ} \mathrm{C}$ (dec.). Anal. calcd for $\mathrm{C}_{36} \mathrm{H}_{46} \mathrm{~N}_{8} \mathrm{Cl}_{4} \mathrm{~F}_{12} \mathrm{O}_{26} \mathrm{~S}_{4} \mathrm{Zn}_{3}$ : C, 25.42; H, 2.73; N, 6.59. Found: C, 25.60; H, 2.51; N, 6.84. $\mathrm{HRESI}^{+}-\mathrm{MS}(\mathrm{MeOH}, \mathrm{m} / \mathrm{z})$ : $292.9639\left(\left[\mathrm{Zn}(\mathrm{OAc})\left(\mathrm{ClC}_{6} \mathrm{H}_{4} \mathrm{C}\left(\mathrm{NH}_{2}\right)=\mathrm{NOH}\right)\right]^{+}\right.$, calcd 292.9666), $404.9625\left(\left[\mathrm{Zn}\left(\mathrm{ClC}_{6} \mathrm{H}_{4} \mathrm{C}\left(\mathrm{NH}_{2}\right)=\mathrm{NOH}\right)_{2}-\mathrm{H}\right]^{+}\right.$, calcd 404.9672), $416.8932\left(\left[\mathrm{Zn}_{2}(\mathrm{OAc})_{2}\left(\mathrm{ClC}_{6} \mathrm{H}_{4} \mathrm{C}\left(\mathrm{NH}_{2}\right)=\mathrm{NOH}\right)-\mathrm{H}\right]^{+}\right.$, calcd 416.8982), $528.8937\left(\left[\mathrm{Zn}_{2}(\mathrm{OAc})\left(\mathrm{ClC}_{6} \mathrm{H}_{4} \mathrm{C}\left(\mathrm{NH}_{2}\right)=\mathrm{NOH}\right)_{2}-2 \mathrm{H}\right]^{+}\right.$, calcd 528.8997), $588.9144\left(\left[\mathrm{Zn}_{2}(\mathrm{OAc})_{2}\left(\mathrm{ClC}_{6} \mathrm{H}_{4} \mathrm{C}\left(\mathrm{NH}_{2}\right)=\mathrm{NOH}\right)_{2}-\mathrm{H}\right]^{+}\right.$, calcd 588.9209), $648.9352\left(\left[\mathrm{Zn}_{2}(\mathrm{OAc})_{3}\left(\mathrm{ClC}_{6} \mathrm{H}_{4} \mathrm{C}\left(\mathrm{NH}_{2}\right)=\mathrm{NOH}\right)_{2}\right]^{+}\right.$, calcd 648.9421). HRESI $^{-}$-MS $(\mathrm{m} / \mathrm{z}): 682.7972\left(\left[\mathrm{Zn}(\mathrm{OTf})_{3}\left(\mathrm{ClC}_{6} \mathrm{H}_{4} \mathrm{C}\left(\mathrm{NH}_{2}\right)=\mathrm{NOH}\right)\right]^{-}\right.$, calcd 682.8064), 896.6801 ([ $\left.\mathrm{Zn}_{2}(\mathrm{OTf})_{4}\left(\mathrm{ClC}_{6} \mathrm{H}_{4} \mathrm{C}\left(\mathrm{NH}_{2}\right)=\mathrm{NOH}\right)-\mathrm{H}\right]^{-}$, calcd 896.6775). IR ( $\mathrm{KBr}$, selected bands, $\left.\mathrm{cm}^{-1}\right)$ : 3422(s), $3314(\mathrm{w}-\mathrm{m}), \quad 3234(\mathrm{~s}) \quad \nu(\mathrm{O}-\mathrm{H})$ and $\nu(\mathrm{N}-\mathrm{H}) ; 2994(\mathrm{sh}), \quad 2898(\mathrm{w})$ $\nu(\mathrm{C}-\mathrm{H}) ; 1670(\mathrm{~s}) \quad \nu(\mathrm{C}=\mathrm{N}) ; 1574(\mathrm{vs}), 1438(\mathrm{~s}), 1406(\mathrm{~s}), 1350(\mathrm{~m})$ $\nu(\mathrm{C}=\mathrm{O}) ; 1250(\mathrm{vs}), 1174(\mathrm{vs}) \nu(\mathrm{S}=\mathrm{O}) .{ }^{1} \mathrm{H} \mathrm{NMR}\left(\left(\mathrm{CD}_{3}\right)_{2} \mathrm{CO}, \delta\right): 7.93$ (s, br, 2H, $\left.\mathrm{NH}_{2}\right), 7.68(\mathrm{~m}, 1 \mathrm{H}, \mathrm{CH}), 7.62(\mathrm{~m}, 1 \mathrm{H}, \mathrm{CH}), 7.52(\mathrm{~m}, 2 \mathrm{H}$, $\mathrm{CH}$ ), 1.95 (s, 3H, $\mathrm{CH}_{3}$ ). CP-MAS TOSS ${ }^{13} \mathrm{C}\left\{{ }^{1} \mathrm{H}\right\}$ NMR $(\delta): 177.82$ $\left(\mathrm{CH}_{3} \mathrm{CO}_{2}\right) ; 152.40(\mathrm{C}=\mathrm{N}) ; 130.61,128.63,124.60(\mathrm{Ar}) ; 119.31,116.28$ $\left(\mathrm{CF}_{3}\right) ; 23.48,22.31,21.36\left(\mathrm{CH}_{3}\right)$.

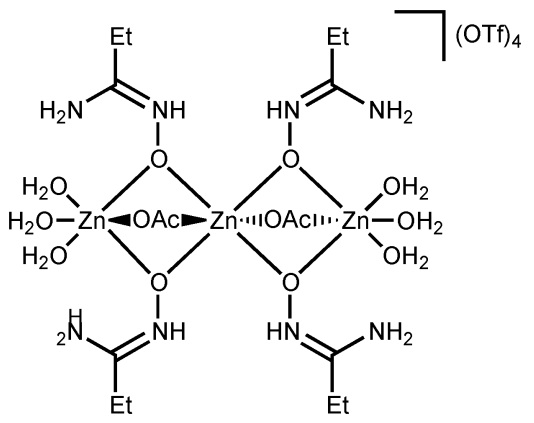

[3c](OTf) . Yield: 73\% (500.4 mg). Mp: $106{ }^{\circ} \mathrm{C}$ (dec.). Anal. calcd for $\mathrm{C}_{20} \mathrm{H}_{50} \mathrm{~N}_{8} \mathrm{~F}_{12} \mathrm{O}_{26} \mathrm{~S}_{4} \mathrm{Zn}_{3}: \mathrm{C}, 17.52 ; \mathrm{H}, 3.68 ; \mathrm{N}$, 8.17. Found: C, 17.77; H, 3.46; N, 8.43. HRESI $^{+}-\mathrm{MS}(\mathrm{MeOH}$, $m / z): 211.0127\left(\left[\mathrm{Zn}(\mathrm{OAc})\left(\mathrm{EtC}\left(\mathrm{NH}_{2}\right)=\mathrm{NOH}\right)\right]^{+}\right.$, calcd 211.0056), $239.0471 \quad\left(\left[\mathrm{Zn}\left(\mathrm{EtC}\left(\mathrm{NH}_{2}\right)=\mathrm{NOH}\right)_{2}-\mathrm{H}\right]^{+}, \quad\right.$ calcd 239.0481), $334.9362\left(\left[\mathrm{Zn}_{2}(\mathrm{OAc})_{2}\left(\mathrm{EtC}\left(\mathrm{NH}_{2}\right)=\mathrm{NOH}\right)-\mathrm{H}\right]^{+}\right.$, calcd 334.9372), $362.9773\left(\left[\mathrm{Zn}_{2}(\mathrm{OAc})\left(\mathrm{EtC}\left(\mathrm{NH}_{2}\right)=\mathrm{NOH}\right)-2 \mathrm{H}\right]^{+}\right.$, calcd 362.9797), $422.9981\left(\left[\mathrm{Zn}_{2}(\mathrm{OAc})_{2}\left(\mathrm{EtC}\left(\mathrm{NH}_{2}\right)=\mathrm{NOH}\right)_{2}-\mathrm{H}\right]^{+}\right.$, calcd 423.0009), 
$483.0202\left(\left[\mathrm{Zn}_{2}(\mathrm{OAc})_{3}\left(\mathrm{EtC}\left(\mathrm{NH}_{2}\right)=\mathrm{NOH}\right)_{2}\right]^{+}\right.$, calcd 483.0221). HRESI $^{-}$-MS $(m / z): 598.8526\left(\left[\mathrm{Zn}(\mathrm{OTf})_{3}\left(\mathrm{EtC}\left(\mathrm{NH}_{2}\right)=\mathrm{NOH}\right)\right]^{-}\right.$, calcd 598.8483). IR (KBr, selected bands, $\mathrm{cm}^{-1}$ ): 3454(s), 3364(s), 3232(s), 3126(m) $\nu(\mathrm{O}-\mathrm{H})$ and $\nu(\mathrm{N}-\mathrm{H}) ; 2994(\mathrm{~m}), 2894(\mathrm{w}-\mathrm{m}) \nu(\mathrm{C}-\mathrm{H})$; 1676(vs) $\nu(\mathrm{C}=\mathrm{N}) ; 1572(\mathrm{vs}), 1444(\mathrm{~s}), 1404(\mathrm{~s}) \nu(\mathrm{C}=\mathrm{O}) ; 1252(\mathrm{vs})$, 1170(vs) $\nu(\mathrm{S}=\mathrm{O}) .{ }^{1} \mathrm{H}$ NMR $\left(\left(\mathrm{CD}_{3}\right)_{2} \mathrm{CO}, \delta\right): 8.44\left(\mathrm{~s}, \mathrm{br}, 2 \mathrm{H}, \mathrm{NH}_{2}\right)$, 2.68, 2.66 (q, 2H, $\left.\mathrm{CH}_{2}\right), 2.02\left(\mathrm{~s}, 3 \mathrm{H}, \mathrm{CH}_{3}\right), 1.35\left(\mathrm{t}, 3 \mathrm{H}, \mathrm{CH}_{3}\right)$. CP-MAS TOSS ${ }^{13} \mathrm{C}\left\{{ }^{1} \mathrm{H}\right\}$ NMR $(\delta): 177.12\left(\mathrm{CH}_{3} \mathrm{CO}_{2}\right) ; 159.71$ $(C=\mathrm{N}), 117.79\left(C \mathrm{~F}_{3}\right) ; 24.93,20.12\left(\mathrm{CH}_{2}\right.$ and $\left.C_{3} \mathrm{CO}_{2}\right) ; 6.70$, $5.89,5.14\left(\mathrm{CH}_{2} \mathrm{CH}_{3}\right)$.

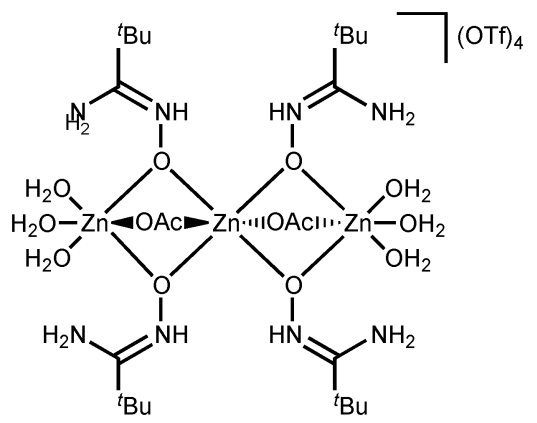

[3d](OTf) 4 . Yield: $70 \%$ (519.1 mg). Mp: $73{ }^{\circ} \mathrm{C}$ (dec.). Anal. calcd for $\mathrm{C}_{28} \mathrm{H}_{66} \mathrm{~N}_{8} \mathrm{~F}_{12} \mathrm{O}_{26} \mathrm{~S}_{4} \mathrm{Zn}_{3}: \mathrm{C}, 22.67 ; \mathrm{H}, 4.48 ; \mathrm{N}, 7.55$. Found: C, 22.44; H, 4.26; N, 7.81. $\mathrm{HRESI}^{+}-\mathrm{MS}(\mathrm{MeOH}, \mathrm{m} / \mathrm{z})$ : $239.0481\left(\left[\mathrm{Zn}(\mathrm{OAc})\left({ }^{t} \mathrm{BuC}\left(\mathrm{NH}_{2}\right)=\mathrm{NOH}\right)\right]^{+}, \quad\right.$ calcd 239.0369), $295.1095\left(\left[\mathrm{Zn}\left({ }^{t} \mathrm{BuC}\left(\mathrm{NH}_{2}\right)=\mathrm{NOH}\right)_{2}-\mathrm{H}\right]^{+}\right.$, calcd 295.1107), 419.0386 $\left(\left[\mathrm{Zn}_{2}(\mathrm{OAc})\left({ }^{t} \mathrm{BuC}\left(\mathrm{NH}_{2}\right)=\mathrm{NOH}\right)_{2}-2 \mathrm{H}\right]^{+}\right.$, calcd 419.0423), 479.0626 $\left(\left[\mathrm{Zn}_{2}(\mathrm{OAc})_{2}\left({ }^{t} \mathrm{BuC}\left(\mathrm{NH}_{2}\right)=\mathrm{NOH}\right)_{2}-\mathrm{H}\right]^{+}\right.$, calcd 479.0635), 539.0819 $\left(\left[\mathrm{Zn}_{2}(\mathrm{OAc})_{3}\left({ }^{t} \mathrm{BuC}\left(\mathrm{NH}_{2}\right)=\mathrm{NOH}\right)_{3}\right]^{+}\right.$, calcd 539.0847). HRESI $^{-}$-MS $(\mathrm{m} / \mathrm{z}): 626.8803\left(\left[\mathrm{Zn}(\mathrm{OTf})_{3}\left({ }^{t} \mathrm{BuC}\left(\mathrm{NH}_{2}\right)=\mathrm{NOH}\right)\right]^{-}\right.$, calcd 626.8796), $840.7540\left(\left[\mathrm{Zn}_{2}(\mathrm{OTf})_{4}\left({ }^{t} \mathrm{BuC}\left(\mathrm{NH}_{2}\right)=\mathrm{NOH}\right)-\mathrm{H}\right]^{-}\right.$, calcd 840.7499). IR (KBr, selected bands, $\left.\mathrm{cm}^{-1}\right)$ : 3446(vs), 3314(vs), 3238(vs) $\nu(\mathrm{O}-\mathrm{H})$ and $\nu(\mathrm{N}-\mathrm{H}) ; 2980(\mathrm{~s}), 2884(\mathrm{~m}) \nu(\mathrm{C}-\mathrm{H}) ; 1668(\mathrm{vs}) \nu(\mathrm{C}=\mathrm{N})$; 1564(s-vs), 1440(s), 1376(s) $\nu(\mathrm{C}=\mathrm{O}) ; 1250(\mathrm{vs}), 1178(\mathrm{vs}) \nu(\mathrm{S}=\mathrm{O})$. ${ }^{1} \mathrm{H}$ NMR ( $\left.\left(\mathrm{CD}_{3}\right)_{2} \mathrm{CO}, \delta\right): 8.37$ (s, br, $\left.2 \mathrm{H}, \mathrm{NH} \mathrm{H}_{2}\right), 2.01\left(\mathrm{~s}, 3 \mathrm{H}, \mathrm{CH}_{3}\right), 1.45$ (s, 9H, $\left.\mathrm{CH}_{3}\right)$. CP-MAS TOSS ${ }^{13} \mathrm{C}\left\{{ }^{1} \mathrm{H}\right\}$ NMR $(\delta): 179.94\left(\mathrm{CH}_{3} \mathrm{CO}_{2}\right)$; $164.47(C=\mathrm{N}) ; 120.62,118.24\left(\mathrm{CF}_{3}\right) ; 34.45,33.30\left(C\left(\mathrm{CH}_{3}\right)_{3}\right)$; 26.38, 25.77, 25.57, $23.30\left(\mathrm{CH}_{3} \mathrm{CO}_{2}\right.$ and $\left.\mathrm{C}\left(\mathrm{CH}_{3}\right)_{3}\right)$.

Preparation of $\left[4 a-c(O T f)_{2}\right]$ and $[5 d](O T f) . \mathrm{Me}_{2} \mathrm{NCN}(161.0 \mu \mathrm{L}$; $2 \mathrm{mmol})$ was added to a stirred solution of $[\mathbf{3 a}-\mathbf{c}](\mathrm{OTf})_{4}$ $(0.5 \mathrm{mmol})$ in EtOAc $(10 \mathrm{~mL})$ (Scheme 2, route $\mathrm{d} 2)$ or to a stirred solution of 1a-c (2 mmol) and $\mathrm{Zn}(\mathrm{OTf})_{2}(363.5 \mathrm{mg} ; 1 \mathrm{mmol})$ in EtOAc $(10 \mathrm{~mL})$ (route e2). The solution was kept for $3 \mathrm{~h}$ at RT and then the resulting precipitate was filtered off, washed by three $1 \mathrm{~mL}$ portions of EtOAc, and dried at $50{ }^{\circ} \mathrm{C}$. The yields are given for route e2. For route $\mathrm{d} 2$, the yields are $93-98 \%$ based on the corresponding [3a-c] $(\mathrm{OTf})_{4}$. In the case of 1d (route e2) or $[3 \mathbf{d}](\mathrm{OTf})_{4}$ (route $\mathrm{d} 2$ ), the reaction results in the precipitation of $[\mathbf{5 d}]($ OTf) in $79 \%$ (route e2) or $98 \%$ (route $\mathrm{d} 2$ ) yields.

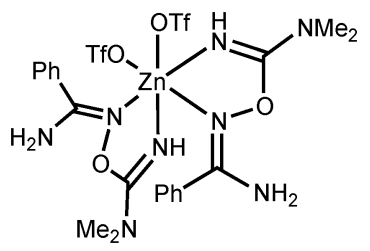

[4a(OTf) $)_{2}$. Yield: $76 \%$ (589.8 mg). $\mathrm{Mp:} 150{ }^{\circ} \mathrm{C}$ (dec.). Anal. calcd for $\mathrm{C}_{22} \mathrm{H}_{28} \mathrm{~N}_{8} \mathrm{~F}_{6} \mathrm{O}_{8} \mathrm{~S}_{2} \mathrm{Zn}$ : C, 34.05; H, 3.64; N, 14.44. Found: C, 34.31; H, 3.86; N, 14.58. HRESI $^{+}-\mathrm{MS}(\mathrm{MeOH}, \mathrm{m} / \mathrm{z})$ : $419.0003\left(\left[\mathrm{M}-\mathrm{PhC}\left(\mathrm{NH}_{2}\right)=\mathrm{NOC}\left(\mathrm{NMe}_{2}\right)=\mathrm{NH}-\mathrm{OTf}\right]^{+}\right.$, calcd 418.9974), 625.1183 ([M - OTf $]^{+}$, calcd 625.1141). HRESI $^{-}$-MS $(m / z): 505.0375\left(\left[\mathrm{PhC}\left(\mathrm{NH}_{2}\right)=\mathrm{NOC}\left(\mathrm{N}\left(\mathrm{CH}_{3}\right)_{2}\right)=\mathrm{NH}_{2}+2 \mathrm{OTf}\right]^{-}\right.$, calcd 505.0281). IR ( $\mathrm{KBr}$, selected bands, $\left.\mathrm{cm}^{-1}\right): 3344(\mathrm{~m}-\mathrm{s})$, 3202(m-s) $\nu(\mathrm{N}-\mathrm{H}) ; 3074(\mathrm{w}), 2948(\mathrm{w}-\mathrm{m}), 2826(\mathrm{w}) \nu(\mathrm{C}-\mathrm{H}) ; 1642(\mathrm{vs})$ $\nu(\mathrm{C}=\mathrm{N}) ; 1286(\mathrm{vs}), 1246(\mathrm{vs}), 1168(\mathrm{vs}) \nu(\mathrm{S}=\mathrm{O}) .{ }^{1} \mathrm{H} \mathrm{NMR}\left(\left(\mathrm{CD}_{3}\right)_{2} \mathrm{SO}\right.$, $\delta)$ : $7.95\left(\mathrm{~s}, \mathrm{br}, 1 \mathrm{H}, \mathrm{NH}_{2}\right), 7.64-7.61\left(\mathrm{~m}, \mathrm{br}, 3 \mathrm{H}, o-\mathrm{CH}\right.$ and $\left.\mathrm{NH}_{2}\right)$, 7.54-7.47 (m, br, 4H, $p-\mathrm{CH}, m-\mathrm{CH}$ and $\left.\mathrm{NH}_{2}\right), 5.18(\mathrm{~s}, 1 \mathrm{H}, \mathrm{NH})$, 2.83 (s, br, 6H, $\left.\mathrm{NMe}_{2}\right) .{ }^{13} \mathrm{C}\left\{{ }^{1} \mathrm{H}\right\} \mathrm{NMR}\left(\left(\mathrm{CD}_{3}\right)_{2} \mathrm{SO}, \delta\right): 160.30,159.28$ $\left(\mathrm{PhC}(=\mathrm{N})-\mathrm{NH}_{2}\right.$ and $\left.\mathrm{OC}(=\mathrm{N}) \mathrm{NMe}_{2}\right) ; 131.85,130.67,128.91$, $128.76(\mathrm{Ph}) ; 121.16$ (q, $\left.C \mathrm{~F}_{3}\right) ; 37.44\left(\mathrm{CH}_{3}\right)$.

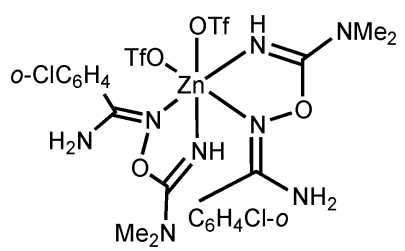

[4b(OTf) $)_{2}$. Yield: $80 \%$ (675.9 mg). Mp: $127{ }^{\circ} \mathrm{C}$ (dec.). Anal. calcd for $\mathrm{C}_{22} \mathrm{H}_{26} \mathrm{~N}_{8} \mathrm{Cl}_{2} \mathrm{~F}_{6} \mathrm{O}_{8} \mathrm{~S}_{2} \mathrm{Zn}$ : C, 31.27; $\mathrm{H}, 3.10 ; \mathrm{N}, 13.26$. Found: C, 31.17; H, 2.91; N, 13.26. $\mathrm{HRESI}^{+}-\mathrm{MS}(\mathrm{MeOH}, \mathrm{m} / \mathrm{z})$ : $695.0393\left(\left[\mathrm{M}-\mathrm{OTf}^{+}\right.\right.$, calcd 695.0334). HRESI $^{-}$-MS $(\mathrm{m} / \mathrm{z})$ : $539.0013\left(\left[o-\mathrm{ClC}_{6} \mathrm{H}_{4} \mathrm{ClC}\left(\mathrm{NH}_{2}\right)=\mathrm{NOC}\left(\mathrm{N}\left(\mathrm{CH}_{3}\right)_{2}\right)=\mathrm{NH}_{2}+2 \mathrm{OTf}\right]^{-}\right.$, calcd 538.9891). IR (KBr, selected bands, $\left.\mathrm{cm}^{-1}\right): 3350(\mathrm{~s})$, 3206(m-s) $\quad \nu(\mathrm{N}-\mathrm{H}) ; \quad 2944(\mathrm{w}-\mathrm{m}) \quad \nu(\mathrm{C}-\mathrm{H}) ; \quad 1638(\mathrm{vs}) \quad \nu(\mathrm{C}=\mathrm{N})$; 1280(vs), 1248(vs), 1160(vs) $\nu(\mathrm{S}=\mathrm{O}) .{ }^{1} \mathrm{H}$ NMR $\left(\left(\mathrm{CD}_{3}\right)_{2} \mathrm{SO}, \delta\right)$ : $7.98\left(\mathrm{~s}, \mathrm{br}, 1 \mathrm{H}, \mathrm{NH}_{2}\right), 7.60\left(\mathrm{~m}, \mathrm{br}, 2 \mathrm{H}, \mathrm{CH}\right.$ and $\left.\mathrm{NH} H_{2}\right), 7.47(\mathrm{~m}$, br, $4 \mathrm{H}, \mathrm{CH}$ and $\mathrm{NH}_{2}$ ), 4.78 (s, $\left.1 \mathrm{H}, \mathrm{NH}\right), 2.80$ (s, br, 3H, NMe), 2.64 (s, br, 3H, NMe). ${ }^{13} \mathrm{C}\left\{{ }^{1} \mathrm{H}\right\} \mathrm{NMR}\left(\left(\mathrm{CD}_{3}\right)_{2} \mathrm{SO}, \delta\right): 159.52,155.68$ $\left(o-\mathrm{ClC}_{6} \mathrm{H}_{4} C(=\mathrm{N}) \mathrm{NH}_{2}\right.$ and $\left.\mathrm{OC}(=\mathrm{N}) \mathrm{NMe}_{2}\right) ; 132.72,132.38,131.52$, 130.33, 129.89, 127.36 (Ar); 121.16 (q, $\left.\mathrm{CF}_{3}\right)$; $37.32\left(\mathrm{CH}_{3}\right)$. Crystals of $[\mathbf{4 b}(\mathrm{OTf})(\mathrm{EtOH})](\mathrm{OTf})$ suitable for X-ray diffraction were obtained by slow evaporation of undried EtOAc solution of the complex at RT in air.

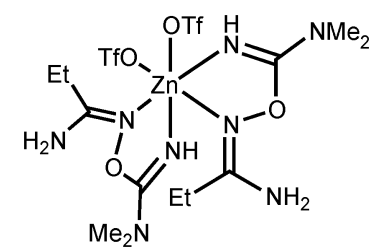

[4c(OTf) $)_{2}$ ]. Yield: $82 \%$ (557.5 mg). Mp: $156{ }^{\circ} \mathrm{C}$ (dec.). Anal. calcd for $\mathrm{C}_{14} \mathrm{H}_{28} \mathrm{~N}_{8} \mathrm{~F}_{6} \mathrm{O}_{8} \mathrm{~S}_{2} \mathrm{Zn}$ : C, 24.73; H, 4.15; N, 16.48. Found: C, 24.85; H, 4.28; N, 16.74. HRESI $^{+}$-MS (MeOH, $\left.m / z\right): 370.9999$ $\left(\left[\mathrm{M}-\mathrm{EtC}\left(\mathrm{NH}_{2}\right)=\mathrm{NOC}\left(\mathrm{NMe}_{2}\right)=\mathrm{NH}-\mathrm{OTf}\right]^{+}\right.$, calcd 370.9974), 529.1189 $\left([\mathrm{M} \text { - OTf }]^{+}\right.$, calcd 529.1141). HRESI $^{-}$-MS (m/z): 457.0401 $\left(\left[\mathrm{EtC}\left(\mathrm{NH}_{2}\right)=\mathrm{NOC}\left(\mathrm{N}\left(\mathrm{CH}_{3}\right)_{2}\right)=\mathrm{NH}_{2}+\mathrm{OTf}\right]^{-}\right.$, calcd 457.0290). IR (KBr, selected bands, $\left.\mathrm{cm}^{-1}\right): 3460(\mathrm{~m}-\mathrm{s}), 3374(\mathrm{~s}), 3224(\mathrm{~m})$ $\nu(\mathrm{N}-\mathrm{H}) ; \quad 2982(\mathrm{~m}), \quad 2946(\mathrm{~m}), \quad 2890(\mathrm{w}-\mathrm{m}) \quad \nu(\mathrm{C}-\mathrm{H}) ; \quad 1642(\mathrm{vs})$ $\nu(\mathrm{C}=\mathrm{N}) ; \quad 1290(\mathrm{vs}), \quad 1244(\mathrm{vs}), \quad 1162(\mathrm{vs}) \quad \nu(\mathrm{S}=\mathrm{O}) . \quad{ }^{1} \mathrm{H} \quad \mathrm{NMR}$ $\left(\left(\mathrm{CD}_{3}\right)_{2} \mathrm{SO}, \delta\right): 7.57$ (s, br, $\left.1 \mathrm{H}, \mathrm{NH}_{2}\right), 7.12$ (s, br, $\left.1 \mathrm{H}, \mathrm{NH}_{2}\right)$, 6.21 (s, 1H, $\mathrm{NH}$ ), 3.02 (s, br, 6H, $\mathrm{NMe}_{2}$ ), 2.20 (q, 2H, $\mathrm{CH}_{2}$ ), $1.19\left(\mathrm{t}, 3 \mathrm{H}, \mathrm{CH}_{3}\right) .{ }^{13} \mathrm{C}\left\{{ }^{1} \mathrm{H}\right\} \mathrm{NMR}\left(\left(\mathrm{CD}_{3}\right)_{2} \mathrm{SO}, \delta\right): 161.23,160.85$ 
$\left(\mathrm{CH}_{2} \mathrm{C}(=\mathrm{N}) \mathrm{NH}_{2}\right.$ and $\left.\mathrm{O} C(=\mathrm{N}) \mathrm{NMe}_{2}\right) ; 121.15\left(\mathrm{q}, C \mathrm{~F}_{3}\right) ; 37.61$ $\left(\mathrm{NMe}_{2}\right) ; 24.61\left(\mathrm{CH}_{2}\right) ; 12.13\left(\mathrm{CH}_{2} \mathrm{CH}_{3}\right)$. Crystals of $\left[4 \mathrm{c}(\mathrm{OTf})_{2}\right]$ suitable for X-ray diffraction were obtained by slow evaporation of wet EtOAc solution of the complex at RT in air.

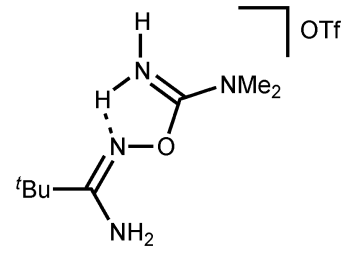

[5d](OTf). Yield: 79\% (531.4 mg). Mp: $120{ }^{\circ} \mathrm{C}$ (dec.). Anal. calcd for $\mathrm{C}_{9} \mathrm{H}_{19} \mathrm{~N}_{4} \mathrm{~F}_{3} \mathrm{O}_{4} \mathrm{~S}$ : C, 32.14; H, 5.69; N, 16.66. Found: $\mathrm{C}$, 32.01; H, 5.47; N, 16.65. HRESI ${ }^{+}-\mathrm{MS}(\mathrm{MeOH}, \mathrm{m} / \mathrm{z}): 187.1584$ $\left([\mathrm{M}]^{+}\right.$, calcd 187.1553), $523.2684\left([2 \mathrm{M}+\mathrm{OTf}]^{+}\right.$, calcd 523.2632). HRESI $^{-}$-MS $(\mathrm{m} / \mathrm{z}): 485.0734$ ([M + 2OTf $]^{-}$, calcd 485.0594). IR ( $\mathrm{KBr}$, selected bands, $\left.\mathrm{cm}^{-1}\right): 3422(\mathrm{vs}), 3360(\mathrm{vs}), 3290(\mathrm{~s}-\mathrm{vs})$, 3242(s-vs) $\quad \nu(\mathrm{N}-\mathrm{H}) ; \quad 2982(\mathrm{~m}-\mathrm{s}), \quad 2882(\mathrm{~m}) \quad \nu(\mathrm{C}-\mathrm{H}) ; \quad 1694(\mathrm{vs})$ $\nu(\mathrm{C}=\mathrm{N})_{\text {oxime }} ; 1652(\mathrm{vs}) \nu(\mathrm{C}=\mathrm{N})_{\text {imine }} ; 1264(\mathrm{vs}), 1162(\mathrm{vs}) \nu(\mathrm{S}=\mathrm{O})$. ${ }^{1} \mathrm{H} \mathrm{NMR}\left(\left(\mathrm{CD}_{3}\right)_{2} \mathrm{SO}, \delta\right): 8.51\left(\mathrm{~s}, \mathrm{br}, 1 \mathrm{H}, \mathrm{NH}_{2}\right), 7.92\left(\mathrm{~s}, \mathrm{br}, 1 \mathrm{H}, \mathrm{NH}_{2}\right)$, $6.63\left(\mathrm{~s}, 2 \mathrm{H}, \mathrm{NH}_{2}\right.$ ), 3.05 (s, 6H, $\mathrm{NMe}_{2}$ ), 1.20 (s, 9H, $\mathrm{CH}_{3}$ ). CP-MAS TOSS $\left.{ }^{13} \mathrm{C}^{1}{ }^{1} \mathrm{H}\right\}$ NMR $(\delta): 162.95,156.86\left(\mathrm{CC}(=\mathrm{N}) \mathrm{NH}_{2}\right.$ and $\left.\mathrm{O} C(=\mathrm{N}) \mathrm{NMe}_{2}\right) ; 116.01\left(C \mathrm{~F}_{3}\right) ; 35.20\left(\mathrm{NMe}_{2}\right) ; 32.96\left(C \mathrm{Me}_{3}\right) ; 24.28$ (Me). Crystals of [5d](OTf) suitable for X-ray diffraction were obtained by slow evaporation of $\mathrm{Me}_{2} \mathrm{CO}$ solution at RT in air.

Preparation of [5a-c](OTf). A solution of trifluoromethanesulfonic acid $(88.3 \mu \mathrm{L} ; 1 \mathrm{mmol})$ in methanol $(1 \mathrm{~mL})$ was dropwise added to a stirred solution of $[\mathbf{4 a - c}](\mathrm{OTf})_{2}(0.5 \mathrm{mmol})$ in methanol $(1 \mathrm{~mL})$ placed in a $5 \mathrm{~mL}$ round-bottomed flask. The solution was kept for $5 \mathrm{~min}$ at RT and then the solvent was evaporated in vacuo at RT. The oily residue was crystallized under ethyl acetate and dried at RT in air.

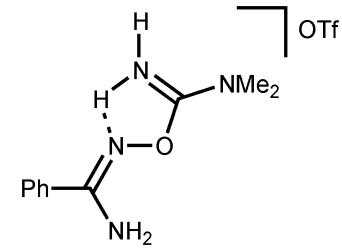

[5a](OTf). Yield: $87 \%$ (310.0 mg). Mp: $129{ }^{\circ} \mathrm{C}$ (dec.). Anal. calcd for $\mathrm{C}_{11} \mathrm{H}_{15} \mathrm{~N}_{4} \mathrm{~F}_{3} \mathrm{O}_{4} \mathrm{~S}: \mathrm{C}, 37.08 ; \mathrm{H}, 4.24 ; \mathrm{N}, 15.72$. Found: $\mathrm{C}$, 37.12; H, 4.05; N, 15.68. HRESI ${ }^{+}-\mathrm{MS}(\mathrm{MeOH}, \mathrm{m} / \mathrm{z}): 207.1240$ $\left([\mathrm{M}]^{+}\right.$, calcd 207.1240), $563.1990\left(\left[2 \mathrm{M}+\mathrm{OTf}^{+}\right.\right.$, calcd 563.2006). HRESI $^{-}$-MS $(\mathrm{m} / \mathrm{z})$ : 505.0292 ([M + 2OTf $]^{-}$, calcd 505.0281). IR (KBr, selected bands, $\left.\mathrm{cm}^{-1}\right)$ : 3442(m-s), 3350(s), 3242(m) $\nu(\mathrm{N}-\mathrm{H}) ; \quad 2958(\mathrm{~m}), \quad 2896(\mathrm{~m}) \quad \nu(\mathrm{C}-\mathrm{H}) ; \quad 1688(\mathrm{vs}) \quad \nu(\mathrm{C}=\mathrm{N})_{\text {oxime }}$; 1654(vs) $\nu(\mathrm{C}=\mathrm{N})_{\text {imine }} ; 1258(\mathrm{vs}), 1168(\mathrm{vs}) \nu(\mathrm{S}=\mathrm{O}) .{ }^{1} \mathrm{H} \quad \mathrm{NMR}$ $\left(\left(\mathrm{CD}_{3}\right)_{2} \mathrm{SO}, \delta\right): 8.68\left(\mathrm{~s}, \mathrm{br}, 2 \mathrm{H}, \mathrm{NH}_{2}\right), 7.87-7.85(\mathrm{~m}, 2 \mathrm{H}, o-\mathrm{CH})$, 7.60-7.56 (m, 1H, p-CH), 7.53-7.49 (m, 2H, m-CH) 7.34 (s, br,

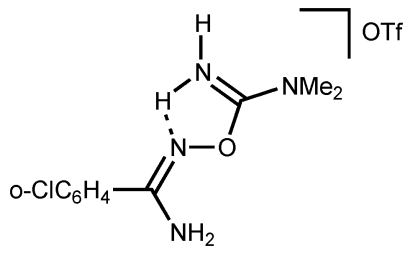

$\left.2 \mathrm{H}, \mathrm{N} H_{2}\right), 3.14$ (s, br, 6H, $\left.\mathrm{NMe}_{2}\right) \cdot{ }^{13} \mathrm{C}\left\{{ }^{1} \mathrm{H}\right\} \mathrm{NMR}\left(\left(\mathrm{CD}_{3}\right)_{2} \mathrm{SO}, \delta\right)$ : 159.96, $158.16\left(\mathrm{PhC}(=\mathrm{N}) \mathrm{NH}_{2}\right.$ and $\left.\mathrm{O} C(=\mathrm{N}) \mathrm{NMe}_{2}\right) ; 131.73$, 130.50, 128.93, $127.86(\mathrm{Ph}) ; 121.17\left(\mathrm{q}, C \mathrm{~F}_{3}\right) ; 38.35,37.27$ $\left(\mathrm{CH}_{3}\right)$. Crystals of [5a](OTf) suitable for X-ray diffraction were obtained by slow evaporation of $\mathrm{Me}_{2} \mathrm{CO}$ solution at RT in air

[5b](OTf). Yield: 92\% (359.5 mg). Mp: $75{ }^{\circ} \mathrm{C}$ (dec.). Anal. calcd for $\mathrm{C}_{11} \mathrm{H}_{14} \mathrm{~N}_{4} \mathrm{ClF}_{3} \mathrm{O}_{4} \mathrm{~S}$ : C, 33.81; H, 3.61; N, 14.34. Found: C, 33.83; H, 3.75; N, 14.29. HRESI ${ }^{+}$-MS (MeOH, $\left.m / z\right): 241.0835$ $\left([\mathrm{M}]^{+} \text {, calcd 241.0851), } 631.1207 \text { ([2M + OTf }\right]^{+}$, calcd 631.1227). HRESI $^{-}$-MS $(\mathrm{m} / \mathrm{z}): 538.9957$ ([M + 2OTf $]^{-}$, calcd 538.9891). IR $\left(\mathrm{KBr}\right.$, selected bands, $\left.\mathrm{cm}^{-1}\right): 3442(\mathrm{~s}), 3348(\mathrm{~s}), 3290(\mathrm{~s}), 3238(\mathrm{~s})$ $\nu(\mathrm{N}-\mathrm{H}) ; \quad 2956(\mathrm{w}), \quad 2858(\mathrm{w}) \quad \nu(\mathrm{C}-\mathrm{H}) ; \quad 1686(\mathrm{vs}) \quad \nu(\mathrm{C}=\mathrm{N})_{\text {oxime }}$; $1650(\mathrm{vs}) \quad \nu(\mathrm{C}=\mathrm{N})_{\text {imine; }}$ 1254(vs), 1172(vs) $\nu(\mathrm{S}=\mathrm{O}) .{ }^{1} \mathrm{H} \quad \mathrm{NMR}$ $\left(\left(\mathrm{CD}_{3}\right)_{2} \mathrm{SO}, \delta\right): 8.74\left(\mathrm{~s}, \mathrm{br}, 1 \mathrm{H}, \mathrm{N} H_{2}\right), 8.48\left(\mathrm{~s}, \mathrm{br}, 1 \mathrm{H}, \mathrm{NH}_{2}\right)$, 7.62-7.54 (m, 5H, m-, $p$-CH and $\left.\mathrm{NH}_{2}\right), 7.49-7.45(\mathrm{~m}, 2 \mathrm{H}, o-\mathrm{CH}$ and $\left.\mathrm{NH}_{2}\right), 3.12\left(\mathrm{~s}, \mathrm{br}, 6 \mathrm{H}, \mathrm{NMe}_{2}\right) \cdot{ }^{13} \mathrm{C}\left\{{ }^{1} \mathrm{H}\right\} \mathrm{NMR}\left(\left(\mathrm{CD}_{3}\right)_{2} \mathrm{SO}, \delta\right)$ : 159.75, $157.34\left(\mathrm{ClC}_{6} \mathrm{H}_{4} C(=\mathrm{N}) \mathrm{NH}_{2}\right.$ and $\left.\mathrm{O} C(=\mathrm{N}) \mathrm{NMe}_{2}\right) ; 132.82$, 132.43, 131.86, 130.68, 130.17, $127.66(\mathrm{Ar}) ; 121.16\left(\mathrm{q}, C \mathrm{~F}_{3}\right)$; $38.29,37.28\left(\mathrm{CH}_{3}\right)$.

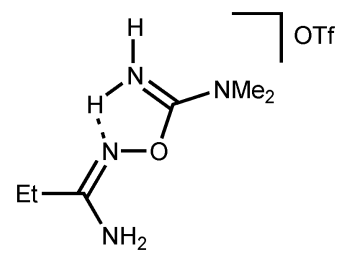

[5c](OTf). Yield: 90\% (277.5 mg). Mp: $103{ }^{\circ} \mathrm{C}$ (dec.). Anal. calcd for $\mathrm{C}_{7} \mathrm{H}_{15} \mathrm{~N}_{4} \mathrm{~F}_{3} \mathrm{O}_{4} \mathrm{~S}: \mathrm{C}, 27.27 ; \mathrm{H}, 4.90 ; \mathrm{N}, 18.17$. Found: $\mathrm{C}$, 27.42; H, 4.79; N, 18.18. HRESI $^{+}-\mathrm{MS}(\mathrm{MeOH}, \mathrm{m} / \mathrm{z}): 159.1231$ $\left([\mathrm{M}]^{+}\right.$, calcd 159.1240), $467.1990\left([2 \mathrm{M}+\mathrm{OTf}]^{+}\right.$, calcd 467.2006). HRESI $^{-}$-MS $(m / z): 457.0290$ ([M + 2OTf $]^{-}$, calcd 457.0280). IR (KBr, selected bands, $\left.\mathrm{cm}^{-1}\right): 3426(\mathrm{~s}), 3358(\mathrm{~s}), 3246(\mathrm{~s}) \nu(\mathrm{N}-\mathrm{H})$; 2988(m), 2952(m), 2892(m) $\nu(\mathrm{C}-\mathrm{H}) ; \quad 1690(\mathrm{vs}) \nu(\mathrm{C}=\mathrm{N})_{\text {oxime }}$; 1666(vs) $\nu(\mathrm{C}=\mathrm{N})_{\text {imine }} ; 1274(\mathrm{vs}), 1160(\mathrm{vs}) \nu(\mathrm{S}=\mathrm{O}) .{ }^{1} \mathrm{H} \quad \mathrm{NMR}$ $\left(\left(\mathrm{CD}_{3}\right)_{2} \mathrm{SO}, \delta\right): 8.63\left(\mathrm{~s}, \mathrm{br}, 1 \mathrm{H}, \mathrm{NH}_{2}\right), 8.37$ (s, br, $\left.1 \mathrm{H}, \mathrm{NH}_{2}\right), 6.97$ (s, br, 1H, NH), 6.78 (s, br 1H, NH), 3.06 (s, br, 6H, $\mathrm{NMe}_{2}$ ), 2.16 (q, 2H, $\left.\mathrm{CH}_{2}\right), 1.15$ (t, 3H, CH$\left.H_{3}\right) .{ }^{13} \mathrm{C}\left\{{ }^{1} \mathrm{H}\right\}$ NMR $\left(\left(\mathrm{CD}_{3}\right)_{2} \mathrm{SO}, \delta\right)$ : 161.89, $159.88\left(\mathrm{CH}_{2} C(=\mathrm{N}) \mathrm{NH}_{2}\right.$ and $\left.\mathrm{OC}(=\mathrm{N}) \mathrm{NMe}_{2}\right) ; 121.14$ (q, $\left.C \mathrm{~F}_{3}\right) ; 38.17,37.09\left(\mathrm{NMe}_{2}\right) ; 24.06\left(\mathrm{CH}_{2}\right) ; 11.91\left(\mathrm{CH}_{3}\right)$.

\section{Acknowledgements}

The work was supported by the Russian Science Foundation (grant 14-13-00060). The authors thank the Center for X-ray Diffraction Studies, Center for Magnetic Resonance, Center for Chemical Analysis and Materials Research, and Chemistry Educational Centre (all belong to Saint Petersburg State University) for the physicochemical measurements.

\section{References}

1 (a) D. S. Bolotin, K. I. Kulish, N. A. Bokach, G. L. Starova, V. V. Gurzhiy and V. Y. Kukushkin, Inorg. Chem., 2014, 53, 10312-10324; (b) J. K. Augustine, V. Akabote, S. G. Hegde 
and P. Alagarsamy, J. Org. Chem., 2009, 74, 5640-5643; (c) V. N. Yarovenko, V. K. Taralashvili, I. V. Zavarzin and M. M. Krayushkin, Tetrahedron, 1990, 46, 3941-3952; (d) V. N. Yarovenko, B. I. Ugrak, M. M. Krayushkin, V. Z. Shirinyan and I. V. Zavarzin, Russ. Chem. Bull., 1994, 43, 627-629; (e) V. N. Yarovenko, I. V. Zavarzin and M. M. Krayushkin, Bull. Acad. Sci. USSR, Div. Chem. Sci., 1986, 35, 1106.

2 O. B. Rajesh, D. Bashir, P. Vidya and F. Mazahar, Mini-Rev. Med. Chem., 2014, 14, 355-369.

3 C. G. Fortuna, R. Berardozzi, C. Bonaccorso, G. Caltabiano, L. Di Bari, L. Goracci, A. Guarcello, A. Pace, A. Palumbo Piccionello, G. Pescitelli, P. Pierro, E. Lonati, A. Bulbarelli, C. E. A. Cocuzza, G. Musumarra and R. Musumeci, Bioorg. Med. Chem., 2014, 22, 6814-6825.

4 M. Chang, Sh. Mobashery, E. Spink, D. Ding, S. Testero, E. Leemans and M. Bouderau, WO2016049586A2, 2016.

5 J. M. dos Santos Filho, D. M. A. de Queiroz e Silva, T. S. Macedo, H. M. P. Teixeira, D. R. M. Moreira, S. Challal, J.-L. Wolfender, E. F. Queiroz and M. B. P. Soares, Bioorg. Med. Chem., 2016, 24, 5693-5701.

6 (a) C. V. Maftei, E. Fodor, P. G. Jones, C. G. Daniliuc, M. H. Franz, G. Kelter, H.-H. Fiebig, M. Tamm and I. Neda, Tetrahedron, 2016, 72, 1185-1199; (b) K. Challa, M. V. Bhargavi and G. L. D. Krupadanam, J. Asian Nat. Prod. Res., 2016, 18, 1158-1168; (c) K. N. Nandeesh, H. A. Swarup, N. C. Sandhya, C. D. Mohan, C. S. Pavan Kumar, M. N. Kumara, K. Mantelingu, S. Ananda and K. S. Rangappa, New J. Chem., 2016, 40, 2823-2828.

7 M. Mohammadi-Khanaposhtani, M. Shabani, M. Faizi, I. Aghaei, R. Jahani, Z. Sharafi, N. Shamsaei Zafarghandi, M. Mahdavi, T. Akbarzadeh, S. Emami, A. Shafiee and A. Foroumadi, Eur. J. Med. Chem., 2016, 112, 91-98.

8 (a) P. G. N. Sasikumar, M. Ramachandra, A. Prasad and S. S. S. Naremaddepalli, WO2016142886A2, 2016; (b) P. G. N. Sasikumar, M. Ramachandra and S. S. S. Naremaddepalli, WO2016142833A1, 2016.

9 S. K. Jain and J. Nandan, World J. Pharm. Pharm. Sci., 2014, 3, 762-773, $712 \mathrm{p}$.

10 W. Zhu, X. Bao, H. Ren, P. Liao, W. Zhu, Y. Yan, L. Wang and Z. Chen, Clin. Exp. Hypertens., 2016, 38, 435-442.

11 D. V. Ziolkovskiy, V. V. Lipson, A. D. Nikitina and V. A. Chebanov, Lett. Drug Des. Discovery, 2016, 13, 226-233.

12 Y. Cao, C. Min, S. Acharya, K.-M. Kim and S. H. Cheon, Bioorg. Med. Chem., 2016, 24, 191-200.

13 M. Donnier-Marechal, D. Goyard, V. Folliard, T. Docsa, P. Gergely, J.-P. Praly and S. Vidal, Beilstein J. Org. Chem., 2015, 11, 499-503.

14 (a) I. Zahanich, I. Kondratov, V. Naumchyk, Y. Kheylik, M. Platonov, S. Zozulya and M. Krasavin, Bioorg. Med. Chem. Lett., 2015, 25, 3105-3111; (b) A. Tolmachev, A. V. Bogolubsky, S. E. Pipko, A. V. Grishchenko, D. V. Ushakov, A. V. Zhemera, O. O. Viniychuk, A. I. Konovets, O. A. Zaporozhets, P. K. Mykhailiuk and Y. S. Moroz, ACS Comb. Sci., 2016, 18, 616-624.

15 (a) E. Girotto, I. H. Bechtold and H. Gallardo, Liq. Cryst., 2016, 43, 1768-1777; (b) I. H. R. Tomi, M. M. Abdul Razzaq Al-Obaidy and A. H. R. Al-Daraji, Liq. Cryst., 2016, DOI: 10.1080/ 02678292.2016.1225837; (c) M. Subrao, D. M. Potukuchi, G. S. Ramachandra, P. Bhagavath, S. G. Bhat and S. Maddasani, Beilstein J. Org. Chem., 2015, 11, 233-241, 239 p.

16 D. Ko, H. A. Patel and C. T. Yavuz, Chem. Commun., 2015, 51, 2915-2917.

17 V. Thottempudi, J. Zhang, C. He and J. M. Shreeve, RSC Adv., 2014, 4, 50361-50364.

18 K. I. Kulish, A. S. Novikov, P. M. Tolstoy, D. S. Bolotin, N. A. Bokach, A. A. Zolotarev and V. Y. Kukushkin, J. Mol. Struct., 2016, 1111, 142-150.

19 D. S. Bolotin, N. A. Bokach and V. Y. Kukushkin, Coord. Chem. Rev., 2016, 313, 62-93.

20 (a) E. Tílvez, G. I. Cárdenas-Jirón, M. I. Menéndez and R. López, Inorg. Chem., 2015, 54, 1223-1231; (b) K. L. Breno, M. D. Pluth, C. W. Landorf and D. R. Tyler, Organometallics, 2004, 23, 1738-1746.

21 (a) P. E. Hansen, Molecules, 2015, 20, 2405-2424; (b) A. Nowroozi, S. Rahmani, A. Eshraghi and K. Shayan, Struct. Chem., 2016, 27, 829-838; (c) M. P. Romero-Fernandez, M. Avalos, R. Babiano, P. Cintas, J. L. Jimenez and J. C. Palacios, Tetrahedron, 2016, 72, 95-104; (d) D. Rusinska-Roszak, J. Phys. Chem. A, 2015, 119, 3674-3687; (e) M. Vatanparast and A. R. Nekoei, Struct. Chem., 2015, 26, 1039-1048; $(f)$ Non-covalent Interactions in the Synthesis and Design of New Compounds, ed. A. M. Maharramov, K. T. Mahmudov, M. N. Kopylovich, and A. J. L. Pombeiro, Wiley, 2016; $(g)$ K. T. Mahmudov, M. N. Kopylovich and A. J. L. Pombeiro, Coord. Chem. Rev., 2013, 257, 1244-1281; (h) M. N. Kopylovich, M. F. C. Guedes da Silva, L. M. D. R. S. Martins, M. L. Kouznetsov, K. T. Mahmudov and A. J. L. Pombeiro, Polyhedron, 2013, 50, 374-382; ( $i$ ) K. T. Mahmudov, M. N. Kopylovich, M. F. C. Guedes da Silva, G. S. Mahmudova, M. Sutradhar and A. J. L. Pombeiro, Polyhedron, 2013, 60, 78-84; (j) M. N. Kopylovich, A. C. C. Nunes, K. T. Mahmudov, M. Haukka, T. C. O. Mac Leod, L. M. D. R. S. Martins, M. L. Kuznetsov and A. J. L. Pombeiro, Dalton Trans., 2011, 40, 2822-2836; ( $k$ ) S. Wanninger, V. Lorenz, A. Subhan and F. T. Edelmann, Chem. Soc. Rev., 2015, 44, 4986-5002; (l) A. B. Davis, R. E. Lambert, F. R. Fronczek, P. J. Cragg and K. J. Wallace, New J. Chem., 2014, 38, 4678-4683; (m) X. Su, T. F. Robbins and I. Aprahamian, Angew. Chem., Int. Ed., 2011, 50, 1841-1844; (n) K. T. Mahmudov, M. N. Kopylovich, M. F. C. Guedes da Silva and A. J. L. Pombeiro, ChemPlusChem, 2014, 79, 1523-1531; (o) K. T. Mahmudov, M. F. C. Guedes da Silva, M. Sutradhar, M. N. Kopylovich, F. E. Huseynov, N. T. Shamilov, A. A. Voronina, T. M. Buslaeva and A. J. L. Pombeiro, Dalton Trans., 2015, 44, 5602-5610; (p) K. T. Mahmudov, M. N. Kopylovich, A. Sabbatini, M. G. B. Drew, L. M. D. R. S. Martins, C. Pettinari and A. J. L. Pombeiro, Inorg. Chem., 2014, 53, 9946-9958; (q) M. N. Kopylovich, K. T. Mahmudov, A. Mizar and A. J. L. Pombeiro, Chem. Commun., 2011, 47, 7248-7250; (r) M. N. Kopylovich, A. Mizar, M. F. C. Guedes da Silva, T. C. O. Mac Leod, K. T. Mahmudov and A. J. L. Pombeiro, Chem. - Eur. J., 2013, 19, 588-600.

22 D. S. Bolotin, V. K. Burianova, A. S. Novikov, M. Y. Demakova, C. Pretorius, P. P. Mokolokolo, A. Roodt, N. A. Bokach, 
V. V. Suslonov, A. P. Zhdanov, K. Y. Zhizhin, N. T. Kuznetsov and V. Y. Kukushkin, Organometallics, 2016, 35, 3612-3623.

23 F. H. Allen, O. Kennard, D. G. Watson, L. Brammer and G. Orpen, J. Chem. Soc., Perkin Trans. 2, 1987, S1-S19.

24 (a) L. Zhu, D. Liu, L. Wu, W. Feng, X. Zhang, J. Wu, D. Fan, X. Lü, R. Lu and Q. Shi, Inorg. Chem. Commun., 2013, 37, 182-185; (b) D. Dey, G. Kaur, A. Ranjani, L. Gayathri, P. Chakraborty, J. Adhikary, J. Pasan, D. Dhanasekaran, A. R. Choudhury, M. A. Akbarsha, N. Kole and B. Biswas, Eur. J. Inorg. Chem., 2014, 3350-3358; (c) R. Olejník, M. Bílek, Z. Růžičková, Z. Hoštálek, J. Merna and A. Růžička, J. Organomet. Chem., 2015, 794, 237-246.

25 E. G. Witte, K. S. Schwochau, G. Henkel and B. Krebs, Inorg. Chim. Acta, 1984, 94, 323-331.

26 L. Xian, G. Tian, C. M. Beavers, S. J. Teat and D. K. Shuh, Angew. Chem., Int. Ed., 2016, 55, 4671-4673.

27 D. Lefevre-Groboillot, S. Dijols, J.-L. Boucher, J.-P. Mahy, R. Ricoux, A. Desbois, J.-L. Zimmermann and D. Mansuy, Biochemistry, 2001, 40, 9909-9917.

28 S.-G. Roh, A. Proust, P. Gouzerh and F. Robert, J. Chem. Soc., Chem. Commun., 1993, 836-838.

29 R. G. Pearson, J. Am. Chem. Soc., 1963, 85, 3533-3539.

30 (a) A. G. Orpen, L. Brammer, F. H. Allen, O. Kennard, D. G. Watson and R. Taylor, J. Chem. Soc., Dalton Trans., 1989, 12, S1-S83; (b) K. F. Konidaris, V. Bekiari, E. Katsoulakou, C. P. Raptopoulou, V. Psycharis, S. P. Perlepes, T. C. Stamatatos and E. Manessi-Zoupa, Inorg. Chim. Acta, 2011, 376, 470-478; (c) K. F. Konidaris, M. Giouli, C. P. Raptopoulou, V. Psycharis, I. I. Verginadis, A. Vasiliadis, A. S. Afendra, S. Karkabounas, E. Manessi-Zoupa and T. C. Stamatatos, Inorg. Chim. Acta, 2013, 396, 49-59.

31 J. Ran and Y.-P. Tong, Struct. Chem., 2011, 22, 1113-1118.

32 M. Werner, J. Berner and P. G. Jones, Acta Crystallogr., Sect. C: Cryst. Struct. Commun., 1996, 52, 72-74.

33 M. Y. Demakova, D. S. Bolotin, N. A. Bokach, G. L. Starova and V. Y. Kukushkin, Inorg. Chim. Acta, 2015, 425, 114-117.

34 R. F. W. Bader, Chem. Rev., 1991, 91, 893-928.

35 (a) A. S. Mikherdov, M. A. Kinzhalov, A. S. Novikov, V. P. Boyarskiy, I. A. Boyarskaya, D. V. Dar'in, G. L. Starova and V. Y. Kukushkin, J. Am. Chem. Soc., 2016, 138, 14129-14137; (b) A. S. Novikov, M. L. Kuznetsov and A. J. L. Pombeiro, Chem. - Eur. J., 2013, 19, 2874-2888; (c) V. N. Mikhaylov, V. N. Sorokoumov, K. A. Korvinson, A. S. Novikov and I. A. Balova, Organometallics, 2016, 35, 1684-1697; (d) X. Ding, M. J. Tuikka, P. Hirva, V. Y. Kukushkin, A. S. Novikov and M. Haukka, CrystEngComm, 2016, 18, 1987-1995; (e) D. M. Ivanov, A. S. Novikov, G. L. Starova, M. Haukka and V. Y. Kukushkin, CrystEngComm, 2016, 18, 5278-5286; $(f)$ T. V. Serebryanskaya, A. S. Novikov, P. V. Gushchin, M. Haukka, R. E. Asfin, P. M. Tolstoy and V. Y. Kukushkin, Phys. Chem. Chem. Phys., 2016, 18, 14104-14112.

36 T. Steiner, Angew. Chem., Int. Ed., 2002, 41, 48-76.
37 D. Roca-Lopez, A. Daru, T. Tejero and P. Merino, RSC Adv., 2016, 6, 22161-22173.

38 (a) L. L. Anderson, Asian J. Org. Chem., 2016, 5, 9-30; (b) A. Badoiu, G. Bernardinelli, J. Mareda, E. P. Kundig and F. Viton, Chem. - Asian J., 2008, 3, 1298-1311; (c) N. A. Bokach, M. L. Kuznetsov and V. Y. Kukushkin, Coord. Chem. Rev., 2011, 255, 2946-2967; (d) L. Maiuolo and A. De Nino, in Targets in Heterocyclic Systems: Chemistry and Properties, ed. O. A. Attanasi, P. Merino and D. Spinelli, 2015, vol. 19, pp. 299-345; (e) V. Nair and T. D. Suja, Tetrahedron, 2007, 63, 12247-12275; $(f)$ H. Pellissier, Tetrahedron, 2007, 63, 3235-3285; ( $g$ ) W. M. Shi, X. P. Ma, G. F. Su and D. L. Mo, Org. Chem. Front., 2016, 3, 116-130; (h) H. Suga and N. Hayashi, in Heterocyclic Supramolecules II, ed. K. Matsumoto, 2009, vol. 18, pp. 119-154.

39 (a) R. Sustmann, Tetrahedron Lett., 1971, 12, 2717-2720;

(b) R. Sustmann, Pure Appl. Chem., 1974, 40, 569-593;

(c) R. Sustmann, Tetrahedron Lett., 1971, 12, 2721-2724.

40 (a) T. A. Steitz and J. A. Steitz, Proc. Natl. Acad. Sci. U. S. A., 1993, 90, 6496; (b) V. Y. Kukushkin and A. J. L. Pombeiro, Inorg. Chim. Acta, 2005, 358, 1-21.

41 (a) L. Palatinus and G. Chapuis, J. Appl. Crystallogr., 2007, 40, 786-790; (b) L. Palatinus and A. van der Lee, J. Appl. Crystallogr., 2008, 41, 975-984; (c) L. Palatinus, S. J. Prathapa and S. van Smaalen, J. Appl. Crystallogr., 2012, 45, 575-580.

42 G. M. Sheldrick, Acta Crystallogr., Sect. C: Struct. Chem., 2015, C71, 3-8.

43 O. V. Dolomanov, L. J. Bourhis, R. J. Gildea, J. A. K. Howard and H. Puschmann, J. Appl. Crystallogr., 2009, 42, 339-341.

44 K. Marakchi, O. K. Kabbaj and N. Komiha, J. Fluorine Chem., 2002, 114, 81-89.

45 M. J. Frisch, G. W. Trucks, H. B. Schlegel, G. E. Scuseria, M. A. Robb, J. R. Cheeseman, G. Scalmani, V. Barone, B. Mennucci, G. A. Petersson, H. Nakatsuji, M. Caricato, X. Li, H. P. Hratchian, A. F. Izmaylov, J. Bloino, G. Zheng, J. L. Sonnenberg, M. Hada, M. Ehara, K. Toyota, R. Fukuda, J. Hasegawa, M. Ishida, T. Nakajima, Y. Honda, O. Kitao, H. Nakai, T. Vreven, J. J. A. Montgomery, J. E. Peralta, F. Ogliaro, M. Bearpark, J. J. Heyd, E. Brothers, K. N. Kudin, V. N. Staroverov, R. Kobayashi, J. Normand, K. Raghavachari, A. Rendell, J. C. Burant, S. S. Iyengar, J. Tomasi, M. Cossi, N. Rega, J. M. Millam, M. Klene, J. E. Knox, J. B. Cross, V. Bakken, C. Adamo, J. Jaramillo, R. Gomperts, R. E. Stratmann, O. Yazyev, A. J. Austin, R. Cammi, C. Pomelli, J. W. Ochterski, R. L. Martin, K. Morokuma, V. G. Zakrzewski, G. A. Voth, P. Salvador, J. J. Dannenberg, S. Dapprich, A. D. Daniels, O. Farkas, J. B. Foresman, J. V. Ortiz, J. Cioslowski and D. J. Fox, Gaussian 09, Revision A.01, Gaussian, Inc., Wallingford CT, 2009.

46 T. Lu and F. Chen, J. Comput. Chem., 2012, 33, 580-592.

47 E. D. Glendening, C. R. Landis and F. Weinhold, Wiley Interdiscip. Rev.: Comput. Mol. Sci., 2012, 2, 1-42. 